\title{
Global variation in the beta diversity of lake macrophytes is driven by environmental heterogeneity rather than latitude
}

\begin{tabular}{|c|c|}
\hline Journal: & Journal of Biogeography \\
\hline Manuscript ID & JBI-16-0363.R2 \\
\hline Manuscript Type: & Original Article \\
\hline Date Submitted by the Author: & $\mathrm{n} / \mathrm{a}$ \\
\hline Complete List of Authors: & $\begin{array}{l}\text { Alahuhta, Janne; University of Oulu, Geography Research Unit } \\
\text { Kosten, Sarian; Radboud Universiteit Nijmegen, Department of Aquatic } \\
\text { Ecology and Environmental Biology } \\
\text { Akasaka, Munemitsu; Tokyo Noko Daigaku, Faculty of Agriculture } \\
\text { Auderset, Dominique; HES-SO Geneve, Institut F.-A. Forel } \\
\text { Azella, Mattia; Universita degli Studi di Cagliari, Department of Life and } \\
\text { Environmental Sciences } \\
\text { Bolpagni, Rossano; Universita degli Studi di Parma Dipartimento di Fisica e } \\
\text { Scienze della Terra Macedonio Melloni, Department of Life Sciences } \\
\text { Bove, Claudia; Universidade Federal do Rio de Janeiro, Departamento de } \\
\text { Botânica, Museu Nacional } \\
\text { Chambers, Patricia; Environment Canada, Environment and Climate } \\
\text { Change Canada } \\
\text { Chappuis, Eglantine; Consejo Superior de Investigaciones Cientificas, } \\
\text { Centre d'Estudis Avançats de Blanes (CEAB) } \\
\text { Ilg, Christiane; University of Applied Sciences and Arts Western } \\
\text { Switzerland, hepia } \\
\text { Clayton, John; National Institute of Water and Atmospheric Research } \\
\text { Limited, National Institute of Water and Atmospheric Research Limited } \\
\text { De Winston, Mary; National Institute of Water and Atmospheric Research } \\
\text { Limited, National Institute of Water and Atmospheric Research Limited } \\
\text { Ecke, Frauke; SLU Institutionen for vatten och miljo, Department of } \\
\text { Aquatic Sciences and Assessment; Sveriges Lantbruksuniversitet } \\
\text { Fakulteten for Naturresurser och Lantbruksvetenskap, Department of } \\
\text { Wildlife, Fish and Environmental Studies } \\
\text { Gacia, Esperanca; Consejo Superior de Investigaciones Cientificas, Centre } \\
\text { d’Estudis Avançats de Blanes } \\
\text { Gecheva, Gana; Plovdivski universitet Paisij Hilendarski, Faculty of Biology } \\
\text { Grillas, Patrick; Tour du Valat, Research Institute for the conservation of } \\
\text { Mediterranean wetlands } \\
\text { Hauxwell, Jennifer; University of Wisconsin Madison, Center for Limnology } \\
\text { Hellsten, Seppo; Suomen ymparistokeskus, Freshwater Centre } \\
\text { Hjort, Jan; University of Oulu, Department of Geography } \\
\text { Hoyer, Mark; University of Florida, School of Forest Resources and } \\
\text { Conservation } \\
\text { Kolada, Agnieszka; National Research Institute, Department of Freshwater } \\
\text { Assessment Methods and Monitoring } \\
\text { Kuoppala, Minna; Suomen ymparistokeskus, Freshwater Centre } \\
\text { Lauridsen, Torben; Aarhus Universitet, Department of Bioscience }\end{array}$ \\
\hline
\end{tabular}


This is the peer reviewed version of the following article: Alahuhta, J., Kosten, S., Akasaka, M., et. al (2017), Global variation in the beta diversity of lake macrophytes is driven by environmental heterogeneity rather than latitude. J. Biogeogr., 44: 1758-1769., which has been published in final form at https://doi.org/10.1111/jbi.12978. This article may be used for non-commercial purposes in accordance With Wiley Terms and Conditions for self-archiving.
$\mathrm{Li}$, En-Hua; Chinese Academy of Sciences, Institute of Geodesy and Geophysics

Balazs, Lukacs; MTA Centre for Ecological Research, Department of Tisza

River Research

Mjelde, Marit; NIVA, Norwegian Institute for Water Research

Mikulyuk, Alison; University of Wisconsin Madison, Center for Limnology

Mormul, Roger; Universidade Estadual de Maringa, Department of Biology

Nishihiro, Jun; Toho Daigaku, Faculty of Sciences

Oertli, Beat; University of Applied Sciences and Arts Western Switzerland, hepia

Rhazi, Laila; Mohammed V University in Rabat, Laboratory of Botany, Mycology and Environment

Rhazi, Mouhssine; Universite Moulay Ismail, Department of Biology Sass, Laura; University of Illinois at Springfield, Illinois Natural History Survey

Schranz, Christine; Bavarian Environment Agency, Bavarian Environment Agency

Sondergaard, Martin; Aarhus Universitet, Department of Bioscience Yamanouchi, Takashi; Toho Daigaku, Faculty of Sciences

Yu, Qing; Chinese Academy of Sciences, State Key Laboratory of Freshwater Ecology and Biotechnology; University of the Chinese Academy of Sciences, University of Chinese Academy of Sciences

Wang, Haijun; Chinese Academy of Sciences, State Key Laboratory of Freshwater Ecology and Biotechnology

Willby, Nigel; University of Stirling, School of Biological and Environmental Sciences

Zhang, Xiao-Ke; Anqing Normal University, School of Life Sciences Heino, Jani; Suomen ymparistokeskus, Natural Environment Centre

Key Words:

Alkalinity range, Altitude range, Aquatic plants, Comparative analysis, Hydrophytes, Latitude, Nestedness, Spatial extent, Species turnover 
1 Article type: Original article

3 Global variation in the beta diversity of lake macrophytes is driven by 4 environmental heterogeneity rather than latitude

8 Janne Alahuhta ${ }^{1 *}$, Sarian Kosten ${ }^{2}$, Munemitsu Akasaka ${ }^{3}$, Dominique Auderset ${ }^{4}$, Mattia Azzella ${ }^{5}$,

9 Rossano Bolpagni ${ }^{6}$, Claudia P. Bove ${ }^{7}$, Patricia A. Chambers ${ }^{8}$, Eglantine Chappuis ${ }^{9}$, Christiane Ilg $10{ }^{10}$, John Clayton ${ }^{11}$, Mary de Winston ${ }^{11}$, Frauke Ecke ${ }^{12,}{ }^{13}$, Esperança Gacia ${ }^{9}$, Gana Gecheva ${ }^{14}$, 11 Patrick Grillas ${ }^{15}$, Jennifer Hauxwell ${ }^{16}$, Seppo Hellsten ${ }^{17}$, Jan Hjort ${ }^{1}$, Mark V. Hoyer ${ }^{18}$, Agnieszka 12 Kolada $^{19}$, Minna Kuoppala ${ }^{17}$, Torben Lauridsen ${ }^{20}$, En-Hua Li ${ }^{21}$, Balázs A. Lukács ${ }^{22}$, Marit 13 Mjelde $^{23}$, Alison Mikulyuk ${ }^{16,24}$, Roger P. Mormul ${ }^{25}$, Jun Nishihiro ${ }^{26}$, Beat Oertli ${ }^{10}$, Laila Rhazi ${ }^{27}$, 14 Mouhssine Rhazi $^{28}$, Laura Sass $^{29}$, Christine Schranz ${ }^{30}$, Martin Søndergaard ${ }^{20}$, Takashi 15 Yamanouchi $^{26}$, Qing $\mathrm{Yu}^{31,32}$, Haijun Wang ${ }^{31}$, Nigel Willby ${ }^{33}$, Xiao-Ke Zhang ${ }^{34}$, Jani Heino ${ }^{35}$

$17{ }^{1}$ Geography Research Unit, University of Oulu. P.O. Box 3000, FI-90014 Oulu, Finland.

$18{ }^{2}$ Department of Aquatic Ecology and Environmental Biology, Institute for Water and Wetland 19 Research, Radboud University, Heyendaalseweg 135, 6525AJ, Nijmegen, The Netherlands

$20{ }^{3}$ Faculty of Agriculture, Tokyo University of Agricultural and Technology, 3-5-8 Saiwaicho, 21 Fuchu, Tokyo 183-8509, Japan 
$22{ }^{4}$ Institut F.-A. Forel, Environmental Sciences, University of Geneva, Bd Carl Vogt 66, CH-1205

23 Geneva, Switzerland.

245 Department of Life and Environmental Sciences, University of Cagliari, Viale S. Ignazio da 25 Laconi 11-1113, 09123 Cagliari, Italy.

$26{ }^{6}$ Department of Life Sciences, University of Parma, Parco Area delle Scienze 11/A, 43124 Parma, 27 Italy

$28{ }^{7}$ Departamento de Botânica, Museu Nacional, Universidade Federal do Rio de Janeiro, Quinta da 29 Boa Vista, 20940-040, Rio de Janeiro, RJ, Brazil.

$30{ }^{8}$ Environment and Climate Change Canada, 867 Lakeshore Rd, Burlington, Ontario, L7S 1A1, 31 Canada

$32{ }^{9}$ Centre d'Estudis Avançats de Blanes (CEAB), Consejo Superior de Investigaciones Científicas 33 (CSIC), C/accés a la Cala St. Francesc 14, 17300 Blanes, Spain.

$34{ }^{10}$ hepia, University of Applied Sciences and Arts Western Switzerland, 150 route de Presinge, $\mathrm{CH}-$ 351254 Jussy /Genève, Switzerland.

$36{ }^{11}$ National Institute of Water and Atmospheric Research Limited, P.O. Box 11115, Hamilton, New 37 Zealand.

$38{ }^{12}$ Department of Aquatic Sciences and Assessment, Swedish University of Agricultural Sciences 39 (SLU), P.O. Box 7050, SE-750 07 Uppsala, Sweden.

$40{ }^{13}$ Department of Wildlife, Fish and Environmental Studies, Swedish University of Agricultural 41 Sciences (SLU), SE-901 83 Umeå, Sweden.

$42{ }^{14}$ Faculty of Biology, University of Plovdiv, Plovdiv, 4000, Bulgaria. 
$43{ }^{15}$ Tour du Valat, Research Institute for the conservation of Mediterranean wetlands, Le Sambuc, 4413200 Arles, France

$45{ }^{16}$ Center for Limnology, University of Wisconsin, 680 N Park St. Madison, Wisconsin, 53704, 10

USA.

$47{ }^{17}$ Finnish Environment Institute, Freshwater Centre. P.O. Box 413, FI-90014 Oulu, Finland.

$48 \quad{ }^{18}$ Fisheries and Aquatic Sciences, School of Forest Resources and Conservation, Institute of Food 49 and Agricultural Services, University of Florida. 7922 NW 71st Street, Gainesville, Florida, 32609, 50 USA.

$51{ }^{19}$ Department of Freshwater Assessment Methods and Monitoring, Institute of Environmental 52 Protection-National Research Institute, Warsaw, Poland.

$53{ }^{20}$ Department of Bioscience, Aarhus University. Vejsøvej 25, 8600 Silkeborg, Denmark.

$54 \quad{ }^{21}$ Key Laboratory for Environment and Disaster Monitoring and Evaluation of Hubei Province, 55 Institute of Geodesy and Geophysics, Chinese Academy of Sciences, Wuhan 430077, China.

$56{ }^{22}$ Department of Tisza River Research, MTA Centre for Ecological Research, Bem tér 18/C, H57 4026, Debrecen, Hungary.

$58{ }^{23}$ Norwegian Institute for Water Research (NIVA), Gaustadalléen 21, 0349 Oslo, Norway.

$59{ }^{24}$ Wisconsin Department of Natural Resources, 2801 Progress Rd. Madison, WI, 53716 USA.

6025 Department of Biology, Research Group in Limnology, Ichthyology and Aquaculture - Nupélia, 61 State University of Maringá, Av. Colombo 5790, Bloco H90, CEP-87020-900, Mringá-PR, Brazil.

$62{ }^{26}$ Faculty of Sciences, Toho University, 2-2-1 Miyama, Funabashi, Chiba, 274-8510, Japan. 
$63 \quad 27$

27 Laboratory of Botany, Mycology and Environment, Faculty of Sciences, Mohammed V

64 University in Rabat, 4 avenue Ibn Battouta B.P. 1014 RP, Rabat, Morocco.

$65{ }^{28}$ Moulay Ismail University, Faculty of Science and Technology, Department of Biology, PB 509,

${ }^{29}$ Illinois Natural History Survey, Prairie Research Institute, University of Illinois, 1816 South Oak 68 Street, Champaign, IL 61820, USA.

$70{ }^{31}$ State Key Laboratory of Freshwater Ecology and Biotechnology, Institute of Hydrobiology,

71 Chinese Academy of Sciences, Wuhan 430072, China.

$72 \quad{ }^{32}$ University of Chinese Academy of Sciences, Beijing 100049, China.

$73{ }^{33}$ Biological \& Environmental Science, University of Stirling, Stirling, FK9 4LA, UK

$74{ }^{34}$ School of Life Sciences, Anqing Normal University, Anqing 246011, China.

7535 Finnish Environment Institute, Natural Environment Centre, Biodiversity. P.O. Box 413, FI90014 Oulu, Finland.

78 *Corresponding author: Department of Geography, University of Oulu. P.O. Box 3000, FI-90014

79 Oulu, Finland. Email: janne.alahuhta@oulu.fi, GSM: +358503662601.

81 Key words: Alkalinity range, Altitudinal range, Aquatic plants, Freshwater ecosystem, 82 Hydrophytes, Latitude, Nestedness, Spatial extent, Species turnover

83 Running title: Beta diversity of aquatic macrophytes 
384 Number of words in the Abstract: 277

5

85 Number of words in main body of the text: 6520 inclusive of abstract, main text and references 


\section{AbSTRACT}

104 Aim: We studied global variation in beta diversity patterns of lake macrophytes using regional data partitioned between species turnover and nestedness within each study region, and 2) which environmental characteristics structure variation in these beta diversity components.

Location: Global

Methods: We used presence-absence data for aquatic macrophytes from 21 regions distributed around the world. We calculated pairwise-site and multiple-site beta diversity among lakes within each region using Sørensen dissimilarity index and partitioned it into turnover and nestedness coefficients. Beta regression was used to correlate the diversity coefficients with regional environmental characteristics.

Results: Aquatic macrophytes showed different levels of beta diversity within each of the 21 study regions, with species turnover typically accounting for the majority of beta diversity, especially in high-diversity regions. However, nestedness contributed $30-50 \%$ of total variation in macrophyte beta diversity in low-diversity regions. The most important environmental factor explaining the three beta diversity coefficients (total, species turnover and nestedness) was altitudinal range, followed by relative areal extent of freshwater, latitude and water alkalinity range.

Main conclusions: Our findings show that global patterns in beta diversity of lake macrophytes are caused by species turnover rather than by nestedness. These patterns in beta diversity were driven by natural environmental heterogeneity, notably variability in altitudinal range (also related to temperature variation) among regions. In addition, a greater range in alkalinity within a region, likely amplified by human activities, was also correlated with increased macrophyte beta diversity. These findings suggest that efforts to conserve aquatic macrophyte diversity should primarily focus on regions with large numbers of lakes that exhibit broad environmental gradients. 


\section{INTRODUCTION}

Understanding broad-scale biodiversity patterns has become a fundamental topic in biogeography and ecology. The importance of explaining these patterns has increased in recent years because they are intimately related to, for example, ecosystem functioning (Symstad et al., 2003) and resilience (Folke et al., 2004), biogeographical regionalization (Divisek et al., 2016), niche conservatism (Alahuhta et al., 2016), species conservation (Brooks et al., 2006) and ecosystem services (Naidoo et al., 2008). Spatial variation in broad-scale diversity patterns is typically driven by natural history (e.g., past dispersal barriers and evolutionary changes), interactions among species (e.g., competition, predation, and mutualism) and biogeography (e.g., distribution of climate zones, productivity and habitat heterogeneity) (Willig et al., 2003; Qian \& Ricklefs, 2007; Soininen et al., 2007; Field et al., 2009; Baselga et al., 2012). Better knowledge of patterns in biodiversity and their basis is also critical for managing and adapting to invasive species, land use changes, landscape and habitat degradation, and increasing temperatures associated with global change (Vörösmarty et al., 2010). Therefore, studies focussing on broad-scale diversity patterns may directly advance both basic and applied research.

One intrinsic component of biodiversity is beta diversity (i.e., among-site differences in species composition). In general, beta diversity indicates the spatial variation of species composition among communities across space (Anderson et al., 2011), and is essentially related to two different processes (Baselga, 2010): species replacement (i.e., turnover, where one species replaces another with no change in richness) and nestedness (i.e., species richness differences due to species gain or loss). Mechanisms responsible for species replacement originate from environmental filtering, 
151 Conversely, nestedness differences stem from species thinning or from other ecological processes 152 (Baselga, 2010; Legendre, 2014), such as physical barriers or human disturbance, that result in species-poor sites being a subset of the richest site in the region. Independent of the dissimilarity measure used to represent beta diversity, it has been reported to decrease with latitude and increase with altitude and area (Jones et al., 2003; Heegaard, 2004; Qian \& Ricklefs, 2007; Soininen et al., 2007; Kraft et al., 2011). Explanations for these patterns in beta diversity stem from effects of energy availability, water-energy dynamics, climatic variability, habitat heterogeneity and human disturbance (Gaston, 2000; Willig et al., 2003; Socolar et al., 2016). However, the majority of studies on beta diversity have been conducted at small spatial extents or using coarse resolution data across broad spatial scales (Kraft et al., 2011; Dobrovolski et al., 2012), exposing the lack of beta diversity studies using fine-resolution data at regional and global scales.

Increasing evidence indicates, however, that patterns in beta diversity depend on the studied ecosystem, organisms and geographical location (Soininen et al., 2007; Dobrovolski et al., 2012; Viana et al., 2016; Wen et al., 2016). Many of the reported patterns in beta diversity concern wellknown, and often charismatic, taxa of terrestrial ecosystems (Qian \& Ricklefs, 2007; Melo et al., 2009; Kraft et al., 2011; Wen et al., 2016) but may be unrepresentative of patterns in beta diversity for organisms in other ecosystems (Soininen et al., 2007). Studies of beta diversity in freshwaters have often proved to be incongruent with those of terrestrial assemblages (Heino, 2011; Hortal et al., 2015). A few studies have suggested that ecological factors or dataset properties associated with freshwater communities may override spatial processes in determining beta diversity (Heino et al., 2015; Viana et al., 2016). One possible explanation for these differences is that terrestrial ecosystems are more directly influenced by climate, whereas water temperatures, which are naturally more important to aquatic organisms, are more stable. Moreover, the physiological constraints of access to water and atmospheric gases are fundamentally different for terrestrial and 
aquatic organisms. Consequently, there is a need to study diversity patterns of freshwater assemblages at regional and global scales to discover whether they follow the general trends evident in terrestrial organisms.

Aquatic macrophytes are among the most under-represented groups in broad-scale studies of freshwater biodiversity, yet they are an integral structural and functional component of freshwater ecosystems (Chambers et al., 2008). Few studies on macrophyte diversity have been conducted at continental or global extents, and these have relied on data scaled to coarse political or biogeographic regions (Chambers et al., 2008; Chappuis et al., 2012), leading to potentially spurious conclusions about species distributions at finer scales (Hortal et al., 2015). Although aquatic macrophyte diversity has been actively studied at local and regional extents, these studies may suffer from ecosystem-specific characteristics (i.e., varying environmental gradients lead species to respond differently to abiotic factors among regions), including variation in underlying environmental gradients among regions (Heino et al., 2015; Viana et al., 2016). For example, aquatic macrophyte diversity studied using similar methods showed a clear decreasing latitudinal gradient in one region, yet a reversed latitudinal gradient in another (Alahuhta et al., 2013; Alahuhta, 2015). Thus, explaining and testing hypotheses related to broad-scale patterns in diversity is difficult with one or a few data sets, and a more general overview demands comparative analysis of multiple data sets (Crow, 1993; Kraft et al., 2011; Heino et al., 2015).

In this paper, we examine pairwise- and multiple-site beta diversity of aquatic macrophytes using data sets for 21 regions from around the world. Specifically, we consider two questions: (1) How is beta diversity of aquatic macrophytes partitioned between species turnover and nestedness across study regions on a global scale? (2) Which environmental factors explain variation in these beta 
diversity components for aquatic macrophytes across study regions? Based on a continental scale study (Viana et al., 2016), we expected that spatial turnover accounts for most of the overall beta diversity. We also assumed that latitude does not strongly structure macrophyte beta diversity (Crow, 1993; Chambers et al., 2008). Instead, we hypothesised that macrophyte beta diversity is mostly explained by variables reflecting variation in local habitat conditions, thus indicating the effect of environmental heterogeneity on beta diversity (Heegaard, 2004; Viana et al., 2016).

\section{MATERIAL AND METHODS}

\section{Macrophyte and explanatory variable data}

We compiled lake macrophyte data for 21 regions with variable sizes from around the world (Fig. 1). Although only one or a few regions are included from some continents (e.g., only Morocco from Africa), our data set covered all major continents inhabitable by aquatic macrophytes (see Chambers et al., 2008). The regions either closely but not entirely followed a country's political border (e.g., Finland and New Zealand), or were delineated based on natural features (e.g., the Paraná River basin in Brazil and a small area in the Nord-Trøndelag county of Norway). The lakes consisted mostly of natural lentic water bodies (i.e., reservoirs were excluded), but were influenced by anthropogenic pressures to varying degrees (e.g., nutrient enrichment, introduced species, water level fluctuation, isolation and fish farming). The data consisted of presence-absence of vascular macrophyte species that grow exclusively in freshwaters (i.e., hydrophytes). The species data were based on empirical or scientific surveys which were performed all or in part by the authors, with the exception of Canada, China and Japan where data were compiled from existing literature (Appendix S1 in Supporting Information). Macrophytes were surveyed using broadly the same methods within each region, enabling us to compare beta diversity patterns across regions and to minimise the 
The explanatory variables calculated for each regional convex hull included region spatial extent $\left(\mathrm{km}^{2}\right)$, altitudinal range (m, Hijlmans et al., 2005), modelled alkalinity range in lakes (mequiv. $1^{-1}$ at 1/16 degrees resolution, Marcé et al., 2015), predicted range of soil organic carbon mass fraction at depth of $1 \mathrm{~m}$ (1 km resolution, Hengl et al., 2014), areal extent of freshwaters expressed as a proportion of region spatial extent, herein referred to as proportion of freshwater $(\%, 1 \mathrm{~km}$ resolution, Latham et al., 2014) and latitude (i.e., coordinate Y originated from each region's centre point) (Table 1). In addition, we examined whether areal extent of artificial surfaces (e.g., surfaces with houses, roads or industrial sites, Latham et al., 2014) as a proportion of region spatial extent (\%), was correlated with the beta diversity coefficients and other explanatory variables. Regional spatial extent was a surrogate for sampling effort, as it was strongly positively associated with both numbers of lakes and number of species present within a region $\left(\mathrm{R}_{\text {Spearman }} \geq 0.64, \mathrm{p}<0.001\right.$, Appendix S3 in Supporting Information), but is also an indicator of environmental heterogeneity (see also Gaston, 2000). In addition, altitudinal range likely illustrates variability in habitats suitable for different macrophytes (Gaston, 2000; Melo et al., 2009), and it simultaneously served as a proxy 
for variation in temperature (correlation with temperature range: $R_{S}=0.92, p<0.001$ ). Altitudinal range was also positively associated with mean altitude $\left(\mathrm{R}_{S}=0.73, \mathrm{p}<0.001\right)$. Following Dormann et

\section{Beta diversity coefficients for different data sets}

We determined beta diversity of aquatic macrophytes using pairwise-site and multiple-site indices based on presence-absence species data within a region. In our study, the pairwise-site index indicated degree of absolute beta diversity within each region, whereas the multiple-site index was used to compare relative differences in beta diversity among regions (Baselga, 2010). For both 
indices, the calculations were based on the Sørensen dissimilarity, resulting in the following three dissimilarity coefficients: 1) Sørensen coefficient (i.e., a measure of overall beta diversity, $\beta_{\text {sor/SoR }}$ ), 2) Simpson coefficient (i.e., a measure of turnover immune to nestedness resulting from species richness differences, $\beta_{\text {sim/SIM }}$ ), and 3) a coefficient measuring nestedness-resultant beta diversity ( $\beta_{\text {sne/SNE }}$, Baselga, 2010; Legendre, 2014). The Simpson coefficient defines species turnover without the influence of richness gradients, whereas the nestedness-resultant component of beta diversity is

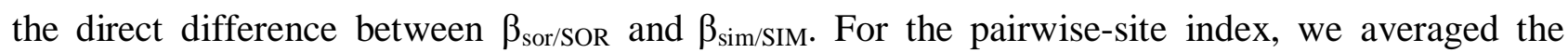
pairwise dissimilarities between all lakes in a region. Because the number of sites affects the multiple-site index (Baselga, 2010), we resampled the 21 regional datasets to standardize them to a common number of 21 lakes, the minimum number of lakes found across the regional datasets (in Brazil Amazon, Table 2), based on 1000 permutations in each region. Both beta diversity indices were obtained using the R package "betapart" (Baselga et al., 2013). The three beta diversity coefficients were calculated using the functions beta.pair and beta.sample for pairwise-site and multiple-site indices, respectively.

\section{Statistical analysis}

We used beta regression to identify which predictor variables explained beta diversity of aquatic macrophytes across the 21 regions. Beta regression, which is an extension of generalized linear models (GLM), was developed for situations where the dependent variable is measured continuously on a standard unit interval between 0 and 1 (Cribari-Neto \& Zeileis, 2010). The models are based on beta distribution with parameterization using mean and precision parameters. Similarly to GLMs, the expected mean is linked to the responses through a link function and a linear predictor. The purpose of the link function is to stabilize the error variance and transform the fitted values to the desired application range (Ferrari \& Cribari-Neto, 2004). Linear regression using 
a logit-transformed response variable is still commonly employed to analyse the type of response

data considered in our work. However, this is questionable, because it (a) may yield fitted values for the variable of interest that exceed its theoretical lower and upper bounds, (b) does not allow parameter interpretation in terms of the response on the original scale, and (c) measures proportions typically displaying asymmetry and, hence, inference based on the normality assumption can be misleading (Ferrari \& Cribari-Neto, 2004). We therefore used beta regression models with a logistic link function, which is asymptotic in the range 0 to 1 (i.e., the predicted values are automatically in the desired application range).

The models with the most important explanatory variables influencing the beta diversity coefficients were selected based on the second order Akaike Information Criterion (AICc) among all model combinations. AICc takes into account sample size by increasing the relative penalty for model complexity with small data sets, and its use is recommended if, as in our case, the ratio between sample size and model parameters is less than 40 (Burnham \& Anderson, 2002). We also examined the possibility of curvilinear relationships between beta diversity coefficients and certain explanatory variables (i.e., region extent, organic carbon and latitude) by entering the quadratic terms of these variables in our models, making the use of AICc even more relevant. In addition, we calculated AIC differences, which can be used to rank different models in order of importance $\left(\mathrm{AIC}_{\mathrm{i}}-\mathrm{AIC}_{\min }\right.$, with $\mathrm{AIC}_{\text {min }}$ representing the best model with respect to expected Kullback-Leibler information lost). Akaike weights derived from AIC differences were estimated for each model to extract additional information on model ranking. We also present pseudo $\mathrm{R}^{2}$ values, which are a squared correlation of linear predictor and link-transformed response and have the same scale as $\mathrm{R}^{2}$ values (between 0 and 1) (Ferrari \& Cribari-Neto, 2004). The relative importance of explanatory variables was evaluated by summing the Akaike weights of the models in which a given variable 


\section{Results}

Beta diversity of aquatic macrophytes differed among the 21 study regions, a finding that was mostly attributable to species turnover (Fig. 2), especially in high beta diversity regions, and applied to both pair-wise and multiple-site indices. Nestedness accounted only for a small fraction of overall beta diversity (14\% of pairwise site dissimilarity on average) and was most important (although still less than species turnover) in regions with low overall pairwise-site beta diversity. Macrophyte beta diversity patterns in the majority of regions were thus explained by variation in species composition among lakes, rather than differences in species richness. Based on the pairwise-site index, the degree of macrophyte beta diversity varied clearly among the 21 study regions. The greatest beta diversity was found in the coastal South American lakes (Salga, 0.90) and Spain (0.92), whereas values were lowest in both the Brazilian regions (0.43-0.44) and China (0.43). The top models obtained through beta regression explained similar amounts of variation and included the same important explanatory variables (Table 2) for both pairwise-site and multiple-site 
3343 beta diversity indices. The best models accounted for $28-33 \%$ of variation in the Sørensen coefficient, $33-37 \%$ in the turnover component and $27-28 \%$ in the nestedness component.

In addition to relationships between beta diversity coefficients and environmental variability, certain environmental variables were correlated with indicators of anthropogenic pressures. Alkalinity range showed a positive relationship with the relative areal extent of artificial surfaces as proportion of region spatial extent $\left(\mathrm{R}_{S}=0.46, \mathrm{p}=0.04\right)$. Both alkalinity range $\left(\mathrm{R}_{S}=0.48, \mathrm{p}=0.03\right)$ and 
3367 temperature range $\left(\mathrm{R}_{\mathrm{S}}=0.56, \mathrm{p}=0.008\right)$ were associated with spatial extent, such that the span in 6368 alkalinity and temperature was greater in regions that covered a greater areal extent. These 7

\section{DISCUSSION}

Aquatic macrophytes exhibited considerable regional variation in beta diversity, which was largely driven by species turnover. Our results thus suggest that turnover in species composition primarily accounts for macrophyte beta diversity. Aquatic macrophytes have similarly shown high levels of species turnover at a regional and continental extent (Heegaard, 2004; Boschilia et al., 2016; Viana et al., 2016). However, our finding conflicts with previous global extent studies on beta diversity in which nestedness contributed equally or more than species turnover to total diversity of amphibians (Baselga et al., 2012), fish (Leprieur et al., 2011), macroinvertebrates (Heino et al., 2015) and oribatid mites (Gergocs \& Hufnagel, 2015). In addition, nestedness has been found to outweigh species turnover in areas affected by glaciations until recent time (Baselga et al., 2012; Dobrovolski et al., 2012). We found no sign of this, as nestedness was typically lowest in regions that were wholly or partly ice covered during the last glaciation (e.g., Finland, Norway, Canada, China, New Zealand, Switzerland, US state of Minnesota and UK). Our study thus emphasises that conclusions about global patterns in beta diversity need verification across a diverse range of organisms, instead of using only a few well-studied terrestrial taxa, because variable patterns exist in nature and exceptions are as instructive as conformity. 
389 Contrary to our a priori expectations based on trends found in terrestrial taxa (Willig et al., 2003;

Qian \& Ricklefs, 2007; Soininen et al., 2007), beta diversity of aquatic macrophytes increased (albeit weakly) towards the poles. Based on Rapoport's rule (Stevens, 1989), species ranges and niche width should increase at higher latitudes, giving rise to a decrease in beta diversity (Soininen et al., 2007). But in general, many aquatic assemblages do not exhibit the latitudinal patterns observed for terrestrial taxa, such as mammals, birds and vascular plants (Heino, 2011; Hortal et al., 2015). Even regarding species richness, one of the most widely-used measures of diversity, aquatic macrophytes show differing responses to latitude at continental and global scales (Rørslett, 1991; Chambers et al., 2008; Chappuis et al., 2012). In addition, contrasting latitudinal patterns in macrophyte beta diversity have been found within individual regions (Heegaard, 2004; Viana et al., 2016), likely due to different study scales and varying sampling techniques used. Our study included only macrophyte data collected via consistent methods (within each region) and showed that overall beta diversity increases weakly from the equator towards the poles. However, the relative importance of latitude in explaining global macrophyte beta diversity was modest, being selected only in two of eleven models. These two models concerned the overall (Sørensen) beta diversity. In contrast, species turnover and nestedness did not vary consistently with latitudinal gradient. This is likely because aquatic macrophytes are more responsive to local environmental conditions than the broad-scale variation in climate that underlies latitudinal gradients in the beta diversity of other (terrestrial) organism groups. Aquatic environments moderate extreme climatic conditions, leading to less variation in temperature in freshwater than terrestrial ecosystems, and this may partly explain the conflict in latitudinal beta diversity patterns between freshwater and terrestrial assemblages.

Although the relationship between latitude and macrophyte beta diversity conflicted with that of many organisms, our results support another reported beta diversity pattern. Habitat heterogeneity 
3414 has previously been shown to structure beta diversity for terrestrial plants (Freestone \& Inouye,

Regional variation in water alkalinity, soil organic carbon availability and spatial extent further indirectly would have supported the habitat heterogeneity hypothesis in explaining global patterns 438 of macrophyte beta diversity. However, contrary to our expectations, these individual variables 
Besides discovering novel patterns in macrophyte beta diversity, our main result has practical implications for environmental management: the conservation of aquatic macrophyte assemblages that naturally exhibit high species turnover will be most favoured by a regional approach, in which multiple lakes that span a wide environmental gradient are protected within a region (Socolar et al., 2016). This approach further underlines the need to maximise the total area protected, independent of the geographical location. Conversely, low biodiversity regions characterized by high nestedness require conservation actions that prioritise high-diversity sites over those of lower diversity (Socolar et al., 2016). In these low-biodiversity regions, the possible influence of land-based activities within a catchment should be carefully evaluated and connectivity among high-diversity habitats should be maintained. 


\section{ACKNOWLEDGEMENTS}

We thank Andres Baselga for insightful comments on the calculation of beta diversity. Comments from Christine Meynard, Solana Boschilia, Chad Larsen and an anonymous reviewer improved the manuscript considerably. We also thank Lucinda B. Johnson and Sidinei M. Thomaz for providing Minnesota and part of the Brazilian data, respectively. We appreciate assistance from Konsta Happonen in producing some of the figures. The gathering of the Finnish data was partly supported by Biological Monitoring of Finnish Freshwaters under diffuse loading -project (XPR3304) financed by Ministry of Agriculture and Forestry and partly by national surveillance monitoring programs of lakes. SH and MM were supported by the EU-funded MARS-project (7th EU Framework Programme, Contract No.: 603378). SALGA-team, especially Gissell Lacerot, Nestor Mazzeo, Vera Huszar, David da Motta Marques and Erik Jeppesen for organizing and executing the SALGA field sampling campaign and Bruno Irgang ${ }^{\dagger}$ and Eduardo Alonso Paz for help with identification. Swedish macrophyte data were collected within the Swedish Monitoring Program of macrophytes in lakes funded by the Swedish Agency for Marine and Water Management. SK was supported by NWO Veni grant 86312012. Macrophyte data from Brazilian Amazon were collected within a limnological monitoring program funded by Vale S.A. The vast majority of macrophyte data from Polish lakes were collected within the State Environmental Monitoring Programme and were provided by the Inspection for Environmental Protection. Macrophyte data for British lakes were collated by the Joint Nature Conservation Committee from surveys resourced by the national conservation agencies. Swiss macrophytes data were collected during a study financially supported by the Swiss Federal Office for the Environment. Wisconsin data collection was funded by the Wisconsin Department of Natural Resources and supported by the Wisconsin Cooperative Fishery Research Unit. The Norwegian macrophyte data were collected within the European Union project 'LAKES - Long distance dispersal of Aquatic Key Species', contract no. env4-ct-97-0585. 
51

52503

53

54

55504

56

57

58505

59

60 


\section{REFERENCES}

Alahuhta, J. \& Heino, J. (2013) Spatial extent, regional specificity and metacommunity structuring in lake macrophytes. Journal of Biogeography, 40, 1572-1582.

Alahuhta, J., Kanninen, A., Hellsten, S., Vuori, K.-M., Kuoppala, M. \& Hämäläinen, H. (2013) Environmental and spatial correlates of community composition, richness and status of boreal lake macrophytes. Ecological Indicators, 32, 172-181.

Alahuhta, J. (2015) Geographic patterns of lake macrophyte communities and species richness at regional scale. Journal of Vegetation Science, 26, 564-575.

Alahuhta, J., Ecke, F., Johnson, L.B., Sass, L. \& Heino, J. (2016) A comparative analysis reveals little evidence for niche conservatism in aquatic macrophytes among four areas on two continents. Oikos, early view. doi: 10.1111/oik.03154

Anderson, M.J., Crist, T.O., Chase, J.M., Vellend, M., Inouye, B.D., Freestone, A.L., Sanders, N.J., Cornell, H.V., Comita, L.S., Davies, K.F., Harrison, S.P., Kraft, N.J., Stegen, J.C. \& Swenson, N.G. (2011) Navigating the multiple meanings of $\beta$ diversity: a roadmap for the practicing ecologist. Ecology Letters, 14, 19-28.

Andrew, M.E., Wulder, M.A., Coops, N.C. \& Baillargeon, G. (2012) Beta-diversity gradients of butterflies along productivity axes. Global Ecology and Biogeography, 21, 352-364.

Bartoń, K. (2014) MuMIn: multi-model inference. R package version 1.12.1.

Baselga, A. (2010) Partitioning the turnover and nestedness components of beta diversity. Global Ecology and Biogeography, 19, 134-143.

Baselga, A., Orme, D., Villeger, S., Bortoli, D. \& Leprieur, F. (2013) betapart: Partitioning beta diversity into turnover and nestedness components. R package version 1.3. 
529 Baselga, A., Gomez-Rodrigues, C. \& Lobo, J.M. (2012) Historical Legacies in World Amphibian 530 Diversity Revealed by the Turnover and Nestedness Components of Beta Diversity. PLoS 7

Boschilia, S.M., de Oliveira, E.F. \& Schwarzbold, A. (2016) Partitioning beta diversity of aquatic macrophyte assemblages in a large subtropical reservoir: prevalence of turnover or nestedness? Aquatic Sciences, 78, 615-625.

Brooks, T.M., Mittermeier, R.A., da Fonseca, G.A.B., Gerlach, J., Hoffmann, M., Lamoreux, J.F., Mittermeier, C.G., Pilgrim, J.D. \& Rodrigues, A.S.L. (2008) Global biodiversity conservation priorities. Science, 313, 58-61.

Burnham, K.P. \& Anderson, D.R. (2002) Model selection and multimodel inference: a practical information-theoretic approach. $2^{\text {nd }}$ edition. Springer-Verlag, New York, NY.

Chambers, P.A., Lacoul, P., Murphy, K.J. \& Thomaz, S.M. (2008) Global diversity of aquatic macrophytes in freshwater. Hydrobiologia, 595, 9-26.

Chappuis, E., Ballesteros, E. \& Gacia, E. (2012) Distribution and richness of aquatic plants across Europe and Mediterranean countries: patterns, environmental driving factors and comparison with total plant richness. Journal of Vegetation Science, 23, 985-997.

Cribari-Neto, F. \& Zeileis, A. (2010) Beta Regression in R. Journal of Statistical Software 34, 1-24.

Crow, G.E. (1993) Species diversity in aquatic angiosperms: latitudinal patterns. Aquatic Botany, 44, 229-258.

Divisek, J., Storch, D., Zelen, D. \& Culek, M. (2016) Towards the spatial coherence of biogeographical regionalizations at subcontinental and landscape scales. Journal of Biogeography, early view. doi: 10.1111/jbi.12832 
Dobrovolski, R., Melo, A.S., Cassemiro, F.A.S. \& Diniz-Filho, J.A.F. (2012) Climatic history and dispersal ability explain the relative importance of turnover and nestedness components of beta diversity. Global Ecology \& Biogeography, 21, 191-197.

Dormann, C.F., Elith, J., Bacher, S., Buchmann, C., Carl, G., Carre, G., Marquéz, J.R.G., Gruber, B., Lafourcade, B., Leitão, P.J., Münkemüller, T., McClean, C., Osborne, P.E., Reineking, B., Schröder, B., Skidmore, A.K., Zurell, D. \& Lautenbach, S. (2013) Collinearity: a review of methods to deal with it and a simulation study evaluating their performance. Ecography, 36, 27-46.

Ferrari, S. \& Cribari-Neto, F. (2004) Beta Regression for modelling rates and proportions. Journal of Applied Statistics, 31, 799-815.

Field, R., Hawkins, B.A., Cornell, H.V., Currie, D.J., Diniz-Filho, J.A.F., Guegan, J.-F., Kaufman, D.M., Kerr, J.T., Mittenbach, G.G., Oberdorff, T., O’Brien, E.M. \& Turner, J.R.G. (2009) Spatial species-richness gradients across scales: a meta-analysis. Journal of Biogeography, 36, 132-147.

Folke, C., Carpenter, S., Walker, B., Scheffer, M., Elmqvist, T., Gunderson, L. \& Holling, C.S. (2004) Regime shifts, resilience, and biodiversity in ecosystem management. Annual Review of Ecology, Evolution, and Systematics, 35, 557-581.

Freestone, A.L. \& Inouye, B.D. (2006) Dispersal limitation and environmental heterogeneity shape scale-dependent diversity patterns in plant communities. Ecology, 87, 2425-2432.

Gaston, K. J. (2000) Global patterns in biodiversity. Nature, 405, 220-227.

Gergocs, V. \& Hufnagel, L. (2015) Global pattern of oribatid mites (Acari: Oribatida) revealed by fractions of beta diversity and multivariate analysis. International Journal of Acarology, 41, 574-583. 
574 Heegaard, E. (2004) Trends in aquatic macrophyte species turnover in Northern Ireland — which 575 factors determine the spatial distribution of local species turnover? Global Ecology and 7

Heino, J. (2011) A macroecological perspective of diversity patterns in the freshwater realm. Freshwater Biology, 56, 1703-1722.

Heino, J., Melo, A.S., Bini, L.M., Altermatt, F., Al-Shami, S.A, Angeler, D., Bonada, N., Brand, C., Callisto, M., Cottenie, K., Dangles, O., Dudgeon, D., Encalada, A., Göthe, E., Grönroos, M., Hamada, N., Jacobsen, D., Landeiro, V.L., Ligeiro, R., Martins, R.T., Miserendino, M. L., Md Rawi, C.S. Rodrigues, M., Roque, F.O., Sandin, L., Schmera, D., Sgarbi, L.F., Simaika, J., Siqueira, T., Thompson, R.M. \& Townsend, C.R. (2015) A comparative analysis reveals weak relationships between ecological factors and beta diversity of stream insect metacommunities at two spatial levels. Ecology and Evolution, 5, 1235-1248.

Hengl, T., de Jesus, J.M., MacMillan, R.A., Batjes, N.H., Heuvelink, G.B.M., Ribeiro, E., SamuelRosa, A., Kempen, B., Leenaars, J.G.B., Walsh, M.G. \& Ruiperez Gonzalez, M. (2014) SoilGrids1km — Global Soil Information Based on Automated Mapping. PLoS ONE, 9, e114788.

Hijlmans, R.J., Cameron, S.E., Parra, J.L., Jones, P.G. \& Jarvis, A. (2005) Very high resolution interpolated climate surfaces for global land areas. International Journal of Climatology, 25, $1965-1978$.

Hortal, J., de Bello, F., Diniz-Filho, J.A.F., Lewinsohn, T.M., Lobo, J.M. \& Ladle, R.J. (2015) Seven Shortfalls that Beset Large-Scale Knowledge of Biodiversity. Annual Review of Ecology, Evolution, and Systematics, 46, 523-549. 
Jones, J.I., Li, W. \& Maberly, S.C. (2003) Area, altitude and aquatic plant diversity. Ecography, 26, $597 \quad 411-420$.

Kolada, A., Willby, N., Dudley, B., Nõges, P., Søndergaard, M., Hellsten, S., Mjedge, M., Penning, E., van Geest, G., Bertrin, V., Ecke, F., Mäemets, H. \& Karus, K. (2014) The applicability of macrophyte compositional metrics for assessing eutrophication in European lakes. Ecological Indicators, 45, 407-415.

Kosten, S., Kamarainen, A., Jeppesen, E., van Nes, E.H., Peeters, E.T.H.M., Mazzeo, N., Sass, L., Hauxwell, J., Hansel-Welch, N., Lauridsen, T.L., Søndergaard, M., Bachmann, R.W., Lacerot, G. \& Scheffer, M (2009) Climate-related differences in the dominance of submerged macrophytes in shallow lakes. Global Change Biology, 15, 2503-2517.

Kraft, N.J.B., Comita, L.S. Chase, J.M., Sanders, N.J., Swenson, N.G., Crist, T.O., Stegen, J.C., Vellend, M., Boyle, B., Anderson, M.J., Cornell, H.V., Davies, K.F., Freestone, A.L., Inouye, B.D., Harrison, S.P. \& Myers, J.A. (2011) Disentangling the Drivers of $\beta$ Diversity Along Latitudinal and Elevational Gradients. Science, 333, 1755-1758.

Latham, J., Cumani, R., Rosati, I. \& Bloise, M. (2014) FAO Global Land Cover (GLC-SHARE) Beta-Release 1.0 Database, Land and Water Division.

Legendre, P. (2014) Interpreting the replacement and richness difference components of beta diversity. Global Ecology and Biogeography, 23, 1324-1334.

Leprieur, F., Tedesco, P.A., Hugueny, B., Beauchard, O., Durr, H.H., Brosse, S. \& Oberdorff, T. (2011) Partitioning global patterns of freshw ater fish beta diversity reveals contrasting signatures of past climate changes. Ecology Letters, 14, 325-334.

Madsen, T.V., Maberly, S.C. \& Bowes, G. (1996) Photosynthetic acclimation of submersed angiosperms to $\mathrm{CO}_{2}$ and $\mathrm{HCO}_{3}{ }^{-}$. Aquatic Botany, 53, 15-30. 
619 Marcé, R., Morgui, J.-A., Riera, J.L., Lopez, P. \& Armengol, J. (2015) Carbonate weathering as a driver of CO2 supersaturation in lakes. Nature Geoscience, 8, 107-111.

Melo, A.S., Rangerl, T.F.L.V.B. \& Diniz-Filho, J.A.F. (2009) Environmental drivers of betadiversity patterns in New-World birds and mammals. Ecography, 32, 226-236.

Naidoo, R., Balmford, A., Costanza, R., Fisher, B, Green, R.E., Lehner, B., Malcolm, T.R. \& Ricketts, T.H. (2008) Global mapping of ecosystem services and conservation priorities. Proceedings of the National Academy of Sciences of the United States of America, 105, 94959500.

Qian, H. \& Ricklefs, R.E. (2007) A latitudinal gradient in large-scale beta diversity for vascular plants in North America. Ecology Letters, 10, 737-744.

Rørslett, B. (1991) Principal determinants of aquatic macrophyte richness in northern European lakes. Aquatic Botany, 39, 173-193.

Rooney, N. \& Kalff, J. (2000) Inter-annual variation in submerged macrophyte community biomass and distribution: the influence of temperature and lake morphometry. Aquatic Botany, 68, 321335.

Scheffer, M., van Geest, G.J., Zimmer, K., Jeppesen, E., Søndergaard, M., Butler, M.G., Hanson, M.A., Declerck, S. \& De Meester, L. (2006) Small habitat size and isolation can promote species richness: second-order effects on biodiversity in shallow lakes and ponds. Oikos, 112, 227-231.

Sculthorpe, C.D. (1967) The biology of aquatic vascular plants. Edward and Arnold Publishing, London. 
Socolar, J.B., Gilroy, J.J., Kunin, W.E. \& Edwards, D.P. (2016) How Should Beta-Diversity Inform Biodiversity Conservation? Trends in Ecology and Evolution, 31, 67-80.

Soininen, J., Lennon, J.J. \& Hillebrand, J. (2007) A Multivariate analysis of beta diversity across organisms and environment. Ecology, 88, 2830-2838.

Stevens, G.C. (1989) The latitudinal gradients in geographical range: how so many species co-exist in the trophics. American Naturalist, 133, 240-256.

Suren, A.M. \& Ormerod, S.J. (1998) Aquatic bryophytes in Himalayan streams: testing a distribution model in a highly heterogeneous environment. Freshwater Biology, 40, 697-716.

Symstad, A.J., Chapin III, F.S., Wall, D.H., Gross, K.L., Huenneke, L.F., Mittelbach, G.G., Peters, D.P. \& Tilman, D. (2003) Long-term and large-scale perspectives on the relationship between biodiversity and ecosystem functioning. Bioscience, 53, 89-98.

Zinger, L., Amaral-Zettler, L.A., Fuhrman, J.A., Horner-Devine, M.C., Huse, S.M., Welch, D.B.M., Martiny, J.B.H., Sogin, M., Boetius, A. \& Ramette, A. (2011) Global Patterns of Bacterial Beta-Diversity in Seafloor and Seawater Ecosystems. PloS ONE, 6, e24570.

Vestergaard, O. \& Sand-Jensen, K. (2000) Alkalinity and trophic state regulate aquatic plant distribution in Danish lakes. Aquatic Botany, 67, 85-107.

Viana, D.S., Figuerola, J., Schwenk, K., Manca, M., Hobæk, A., Mjelde, M., Preston, C.D., Gornall, R.J., Croft, J.M., King, R.A., Green, A.J. \& Santamaria, L. (2015) Assembly mechanisms determining high species turnover in aquatic communities over regional and continental scales. Ecography, 38, 1-8. 
660 Vörösmarty, C.J., McIntyre, P.B., Gessner, M.O., Dudgeon, D., Prusevich, A. Green, P., Glidden, 661 S., Bunn, S.E., Sullivan, C.A., Reidy Liermann, C. \& Davies, P.M. (2010) Global threats to human water security and river biodiversity. Nature, 467, 555-561.

10

Wang, J.J., Soininen, J., Zhang, Y, Wang, B.X., Yang, X.D. \& Shen, J. (2012) Patterns of elevational beta diversity in micro- and macroorganisms. Global Ecology and Biogeography, 21, 743-750.

Wen, Z., Yang, Q., Quan, Q., Xia, L., Ge, D. \& Lv, X (2016) Multiscale partitioning of small mammal $\beta$-diversity provides novel insights into the Quaternary faunal history of QinghaiTibetan Plateau and Hengduan Mountains. Journal of Biogeography, 43, 1412-1424.

Willig, M.R., Kaufman, D.M. \& Stevens, R.D. (2003) Latitudinal Gradients of Biodiversity: Pattern, Process, Scale, and Synthesis. Annual Review of Ecology, Evolution, and Systematics, 34, 273-309. 


\section{BIOSKETCH}

Janne Alahuhta is a postdoctoral researcher in the University of Oulu. His research integrates biogeography, macroecology, community ecology and conservation ecology to study patterns and processes structuring aquatic plants at various spatial scales. He is especially interested to understand how global change affects aquatic macrophyte distributions across temporal and spatial scales. The research group is devoted to the study of aquatic plants and other freshwater assemblages from different perspectives at various spatial scales. Author contributions: J.A. and J.H. conceived the ideas; all authors participated in the collection of the data; J.A. analysed the data; and J.A. led the writing to which other authors contributed.

Editor: Serban Proches 
Table 1. Explanatory variables used in the study and the number of lakes and species within each region. Negative latitude (Y) values were converted to positive in the analysis to strengthen the relationship between beta diversity coefficients and latitude. Extent: Spatial extent of a region, Organic C: Soil organic carbon range, Waters: areal extent of water within a region as proportion of total spatial extent, Y: latitude.

\begin{tabular}{|c|c|c|c|c|c|c|c|c|}
\hline Region & $\begin{array}{l}\text { Number } \\
\text { of lakes }\end{array}$ & $\begin{array}{l}\text { Number } \\
\text { of } \\
\text { species }\end{array}$ & $\begin{array}{l}\text { Alkalinity range } \\
\text { (mequiv. } \mathbf{l}^{-1} \text { ) }\end{array}$ & $\begin{array}{l}\text { Altitudinal } \\
\text { range }(\mathbf{m})\end{array}$ & $\begin{array}{l}\text { Extent } \\
\left(\mathbf{k m}^{2}\right)\end{array}$ & $\begin{array}{l}\text { Org. C } \\
\text { (mass } \\
\text { fraction) } \\
\end{array}$ & $\begin{array}{l}\text { Waters } \\
(\%)\end{array}$ & $\mathbf{Y}$ \\
\hline Brazil, Amazon & 21 & 27 & 0.01 & 603 & 943 & 4 & 0.23 & -6.23 \\
\hline Brazil, Paraná River & 29 & 37 & 0.79 & 17 & 368 & 18 & 21.08 & -22.78 \\
\hline Canada & 58 & 82 & 3.95 & 242 & 82540 & 33 & 21.72 & 44.78 \\
\hline China & 36 & 100 & 4.75 & 1374 & 151400 & 20 & 13.36 & 30.78 \\
\hline Denmark & 32 & 77 & 4.33 & 156 & 17260 & 30 & 10.67 & 56.08 \\
\hline Finland & 261 & 98 & 3.55 & 923 & 315900 & 110 & 10.50 & 64.32 \\
\hline Hungary & 50 & 39 & 0.59 & 375 & 25740 & 12 & 1.56 & 47.28 \\
\hline Italy & 22 & 60 & 4.04 & 3637 & 37980 & 20 & 2.20 & 44.68 \\
\hline Japan & 49 & 93 & 3.20 & 3683 & 216600 & 28 & 1.40 & 38.24 \\
\hline Morocco & 33 & 54 & 4.33 & 2322 & 36520 & 7 & 0.51 & 34.18 \\
\hline New Zealand & 205 & 88 & 4.58 & 2800 & 250800 & 48 & 22.16 & 41.10 \\
\hline Norway & 30 & 30 & 0.00 & 309 & 724 & 17 & 23.01 & 64.90 \\
\hline Poland & 475 & 84 & 4.34 & 289 & 175000 & 22 & 1.99 & 52.99 \\
\hline $\begin{array}{l}\text { Salga project (Brazil, Uruguay and } \\
\text { Argentina) }\end{array}$ & 67 & 28 & 3.63 & 2119 & 299300 & 57 & 3.88 & -32.98 \\
\hline Spain & 66 & 56 & 4.67 & 3129 & 34480 & 19 & 2.98 & 42.04 \\
\hline Sweden & 379 & 101 & 4.68 & 1853 & 403600 & 68 & 10.99 & 62.24 \\
\hline Switzerland & 92 & 60 & 3.18 & 3633 & 26910 & 35 & 4.93 & 46.93 \\
\hline UK & 1928 & 127 & 4.81 & 1219 & 174000 & 81 & 2.28 & 54.24 \\
\hline US state of Florida & 205 & 57 & 4.45 & 112 & 104200 & 66 & 5.14 & 28.99 \\
\hline US state of Minnesota & 441 & 65 & 4.31 & 477 & 152700 & 58 & 7.09 & 46.26 \\
\hline US state of Wisconsin & 409 & 102 & 3.93 & 397 & 141900 & 22 & 5.62 & 44.72 \\
\hline
\end{tabular}


Table 2. Summary of best models explaining variation in aquatic macrophyte beta diversity for multiple-site and pair-wise dissimilarities within a region. Models were calculated for Sørensen dissimilarity (total beta diversity), Simpson dissimilarity (beta diversity due to turnover) and nestedness dissimilarity (beta diversity due to nestedness-resultant richness differences). Best models with delta $<2$ are presented, because these models are typically considered to have similar statistical support (Burnham \& Anderson, 2002). Waters: Proportion of water within a region, df: degree of freedom, delta: AICc difference between model i and the model with the smallest AICc, Weight: Akaike weight, pseudo R²: Maximum likelihood coefficients of determination were obtained through an iterative process.

\begin{tabular}{|c|c|c|c|c|c|c|c|c|c|c|c|}
\hline Multiple site beta diversity & & 4 & 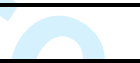 & & & Pair-wise beta diversity & & & & & \\
\hline Sørensen & $\overline{\mathrm{AICc}}$ & $\mathrm{df}$ & $\triangle \mathrm{AICc}$ & $\begin{array}{l}\text { Weigh } \\
\mathrm{t}\end{array}$ & $\begin{array}{l}\text { Pseudo } \\
\mathrm{R}^{2}\end{array}$ & Sørensen & $\mathrm{AICc}$ & $\mathrm{df}$ & $\triangle \mathrm{AICc}$ & $\begin{array}{l}\text { Weigh } \\
\mathrm{t}\end{array}$ & $\begin{array}{l}\text { Pseudo } \\
\mathrm{R}^{2}\end{array}$ \\
\hline Altitudinal range & -80.9 & 3 & 0 & 0.435 & 0.282 & Altitudinal range & -21.9 & 3 & 0 & 0.719 & 0.283 \\
\hline Altitudinal range+Latitude & -79.6 & 4 & 1.34 & 0.223 & 0.317 & $\begin{array}{l}\text { Altitudinal } \\
\text { range+Latitude }\end{array}$ & -20.0 & 4 & 1.88 & 0.281 & 0.301 \\
\hline Altitudinal range+Waters & -79.1 & 4 & 1.74 & 0.182 & 0.326 & & & & & & \\
\hline $\begin{array}{l}\text { Altitudinal range+Alkalinity } \\
\text { range }\end{array}$ & -78.9 & 4 & 1.99 & 0.160 & 0.309 & & & & & & \\
\hline Species turnover & & & & & & Species turnover & & & & & \\
\hline Altitudinal range & -57.2 & 3 & 0 & 0.708 & 0.325 & Altitudinal range & -14.7 & 3 & 0 & 1 & 0.326 \\
\hline Altitudinal range+Waters & -55.4 & 4 & 1.77 & 0.292 & 0.366 & & & & & & \\
\hline Nestedness & & & & & & Nestedness & & & & & \\
\hline Altitudinal range & -83.9 & 3 & 0 & 1 & 0.280 & Altitudinal range & -62.8 & 3 & 0 & 1 & 0.269 \\
\hline
\end{tabular}


Table 3. Relative importance (I) of explanatory variables among all model compilations ( $\mathrm{n}=32) .1 .00$ indicates that the particular variable is selected in all models, whereas 0 represents that the variable is not selected in any of the models. "“+” indicates positive and "“- negative relation between the beta diversity coefficient and that environmental variable. If a given variable was not included among the most important beta diversity models (AICc < 2.0), then the direction of influence was obtained from a full model including all the candidate variables. I: Importance, D: Direction of influence, Altitude: Altitudinal range, Alkalinity: Alkalinity range, Extent: Spatial extent of a region, Organic C: Soil organic carbon range, Waters: areal extent of water within a region as proportion of total spatial extent.

\begin{tabular}{|c|c|c|c|c|c|c|c|c|c|c|c|c|}
\hline & Multiple s & te $b$ & ta diversit & & 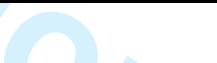 & & Pair-wise & beta & diversity & & & \\
\hline & Sørensen & & $\begin{array}{l}\text { Species } \\
\text { turnover }\end{array}$ & & Nestedness & & Sørensen & & $\begin{array}{l}\text { Species } \\
\text { turnover }\end{array}$ & & Nestedness & \\
\hline & I & D & I & D & I & D & I & D & I & D & I & D \\
\hline Altitude & 0.80 & + & 0.90 & + & 0.85 & - & 0.82 & + & 0.90 & + & 0.89 & - \\
\hline Waters & 0.33 & - & 0.30 & - & 0.23 & + & 0.26 & - & 0.25 & - & 0.17 & + \\
\hline Latitude & 0.32 & + & 0.24 & + & 0.18 & - & 0.26 & + & 0.21 & + & 0.18 & - \\
\hline Alkalinity & 0.25 & + & 0.22 & + & 0.20 & - & 0.24 & + & 0.22 & + & 0.17 & - \\
\hline Organic & 0.16 & - & 0.19 & - & 0.20 & - & 0.16 & - & 0.16 & + & 0.17 & - \\
\hline \multicolumn{13}{|l|}{$\mathrm{C}$} \\
\hline Extent & 0.16 & - & 0.17 & - & 0.20 & - & 0.16 & - & 0.16 & - & 0.17 & + \\
\hline
\end{tabular}




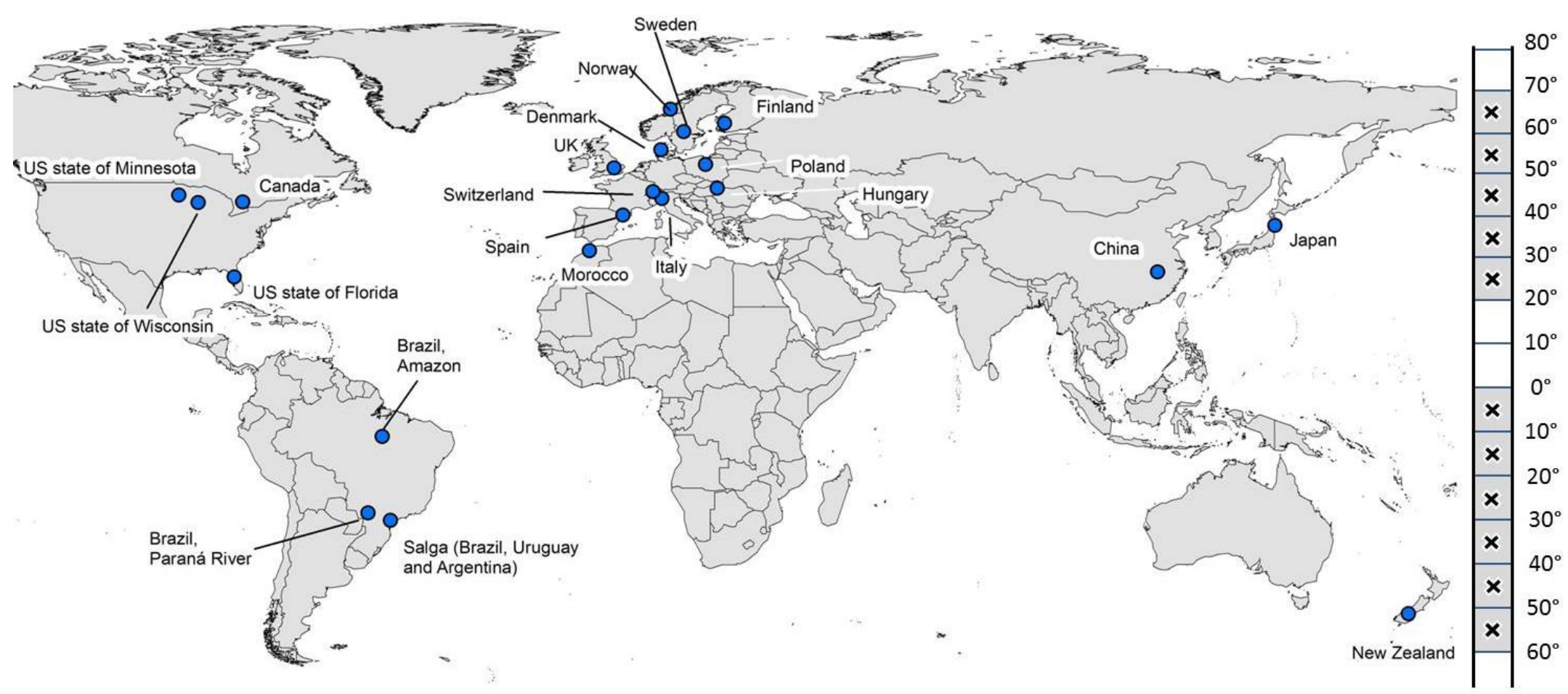

Fig. 1. Study regions are represented in blue circles situated in the middle of convex hulls $(n=21)$. Crosses in the right side panel indicate which latitudinal bands are covered in our work. 


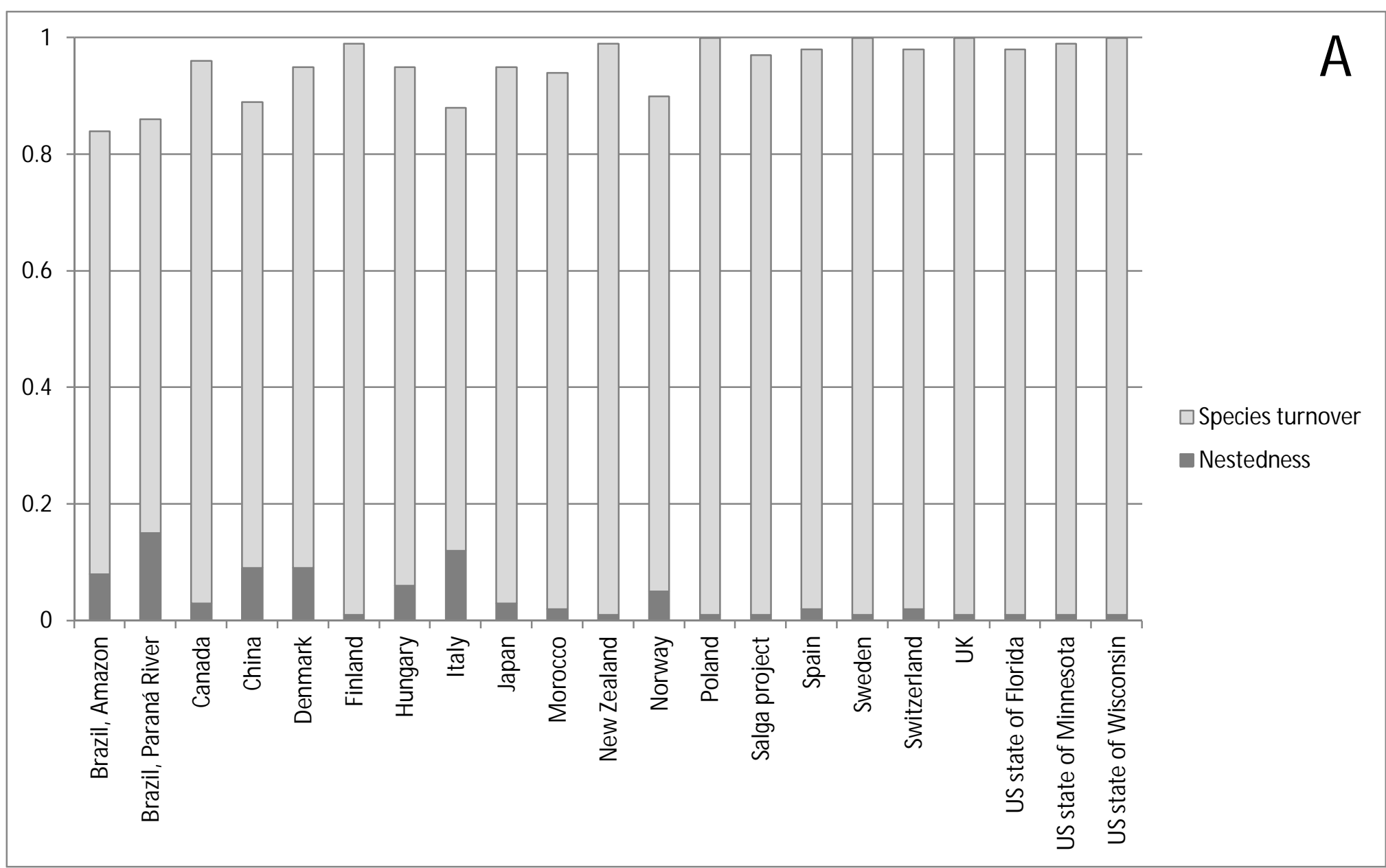




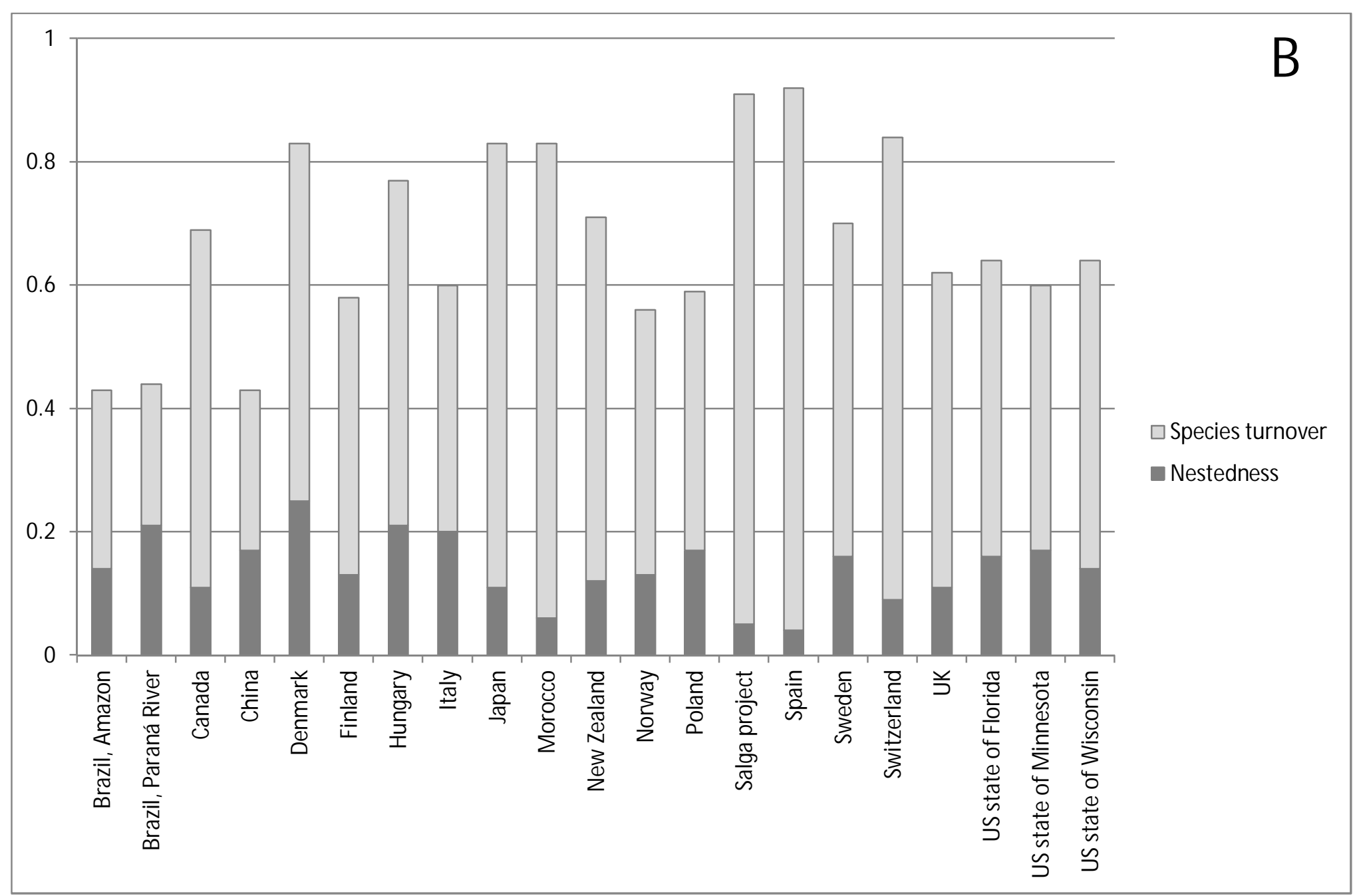

Fig. 2. Simpson dissimilarity (beta diversity due to species turnover) and nestedness dissimilarity (beta diversity due to nestedness-resultant richness differences) that sum to Sørensen dissimilarity (i.e., total beta diversity) based on multiple site (A) and mean of pair-wise (B) beta diversity measures for each study region. Multiple-site beta diversity was based on 21 randomly-selected lakes for each region (except for Brazil, Amazon which had a total $\mathrm{n}$ of 21). 


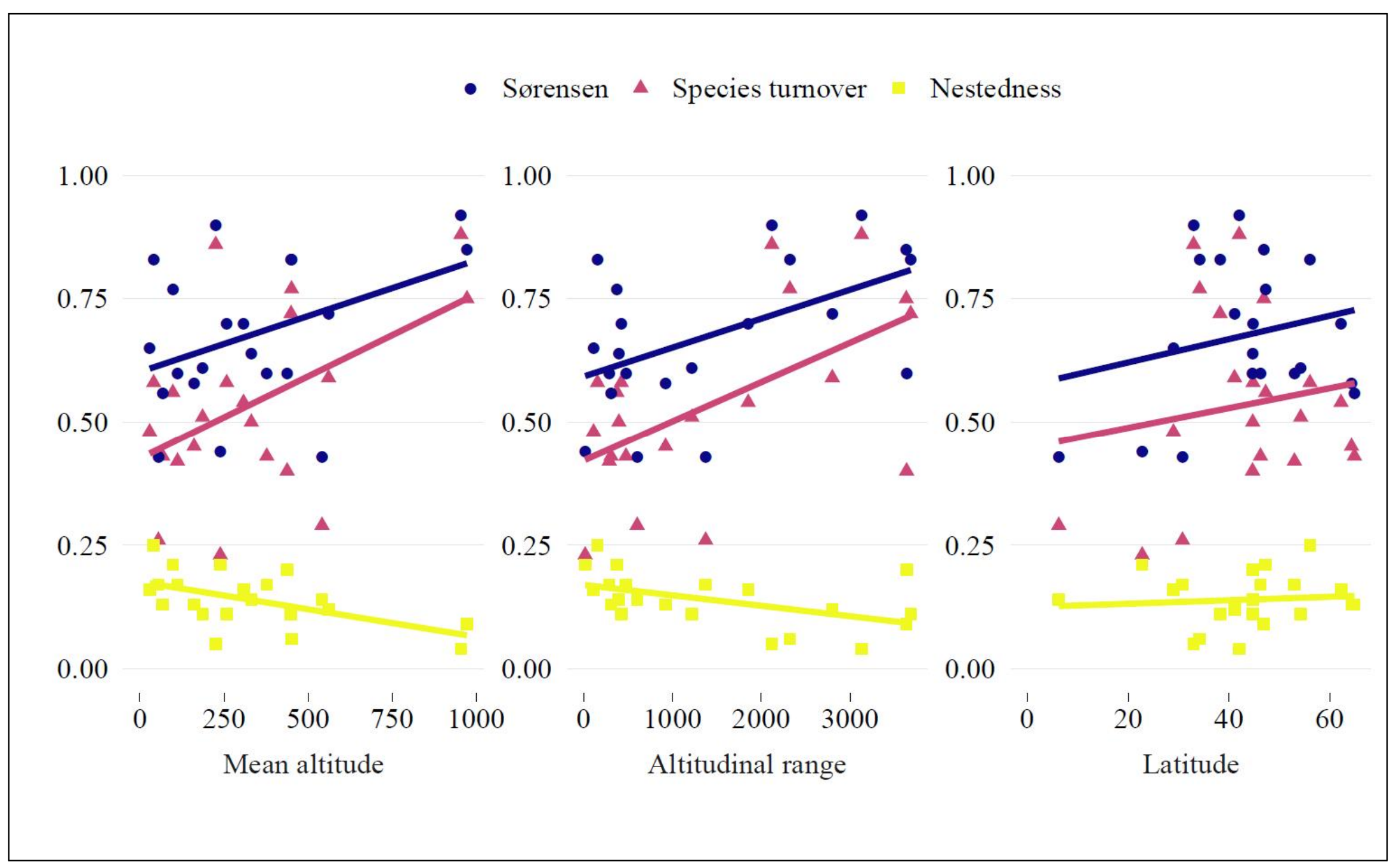

Fig. 3. Relationships between pairwise site beta diversity dissimilarities (i.e., Sørensen, species turnover and nestedness) and mean altitude, altitudinal range and latitude. Similar plot for multiple site beta diversity coefficients can be found in Appendix S4. 
Global variation in the beta diversity of lake macrophytes is driven by environmental heterogeneity rather than latitude

\author{
Janne Alahuhta et al. \\ Journal of Biogeography
}

Supporting Information

16

17

18

19

20

21

22

23

24

25

26

27

28

29

30

31

32

33

34

35

36

37

38

39

40

41

42

43

44

45

46

47

48

49

50

51

52

53

54

55

56

57

58

59

60 
Appendix S1. Description of study lakes and macrophyte survey methods in each region.

\section{Brazil, Amazon}

The sampled lakes are temporary upland lakes located in the National Forest of Carajás-Pará, Brazil. Most sampled lakes are slightly acid and the surrounding area has a soil rich in iron ore. The presence of aquatic macrophyte species was recorded in 21 lakes by observation while walking over the macrophyte stands near the shoreline (parallel to the lake) and in a transect (perpendicularly to the lake) that crosses the lake. Samplings were carried out twice a year during 2004-2005 and 20102011 , and the pooled data was used in the analyses.

\section{Brazil, Paraná River}

Sampled lakes in the Upper Paraná River floodplain are characterized as shallow floodplain lakes, which may be permanently connected with the main river channel or may be isolated with a temporary connection with the main river (during the floods). These lakes vary in $\mathrm{pH}$ (from acid to alkaline), water transparency (from clear to turbid water) and nutrient concentration (from oligotrophic to eutrophic). In all lakes we recorded aquatic macrophytes presence by boat at a slow speed along the entire lake shoreline. We also carried out species records on foot in the shoreline using a transect. We used a grapple, treble hooks and a rake to record submersed species. In this area, we sampled 29 lakes quarterly during 2010.

\section{Britain}

The lakes used are a subset of the 3500 sites surveyed by the Nature Conservancy Council or its successor national conservation agencies, mainly Scottish Natural Heritage, between 1980 and 1998. Sites are mostly in Scotland and typically small ( $<50 \mathrm{ha})$ shallow ( $<3 \mathrm{~m}$ average depth) and oligotrophic, although the dataset includes base-rich lowland lakes in the southern Britain. Sites varied from near-pristine to moderately degraded. Surveys were carried out from June-mid September by two observers, normally experienced botanists, circumnavigating the shoreline on foot to wading depth, using a rake to collect samples from deeper water and also checking strandline material. In larger water bodies wading surveys were complemented by use of a boat to collect samples from deeper water or inaccessible locations. Aquatic and emergent plants were identified to species and their abundance assessed visually on a 5-point scale. Voucher specimens were retained in a herbarium and sent to national experts for verification. Further details are provided in Duigan et al. (2007). 


\section{Canada}

The 58 study sites were located in southern Ontario with the majority $(n=50)$ being individual lakes situated north to north-east of Toronto in the Sudbury, Killarney, Muskoka, Haliburton and Kawartha lake districts. The remaining data are from one lake in eastern Ontario and 6 sites in Lake St. Clair (a connecting lake in the Great Lakes system). With the exception of one study, the data are from the 1970s. At the time of the surveys, the more southerly lakes were mesotrophic to eutrophic (as a result of urban or rural settlement and agricultural influences). In contrast, the more northerly lakes were the typical soft-water, unbuffered water bodies characteristic of the Precambrian Shield but with varying exposure to acidifying emissions. For the majority $(n=42)$, macrophytes were sampled along transect lines that extended from shore to the maximum depth of colonization. For the remainder $(n=16)$, macrophytes were sampled at specific locations. Species lists are provided in Ontario Ministries of Environment and Natural Resources (1976), Crowder et al. (1977), Wile and Hitchin (1977), Miller \& Dale (1979), Hitchin et al. (1984), Schloesser et al. 1984, and Neil et al. (1991).

\section{China}

Most of the studied lakes are located in the mid-lower Yangtze Basin. The lake depths varied between 1 and 12 metres. Many of them are facing intensive human activities, including fishery, eutrophication and river-lake isolation. Macrophytes were surveyed using a belt transect method. The number of transects varied according to a lake size. Field surveys were conducted usually three or four times during a growing season and the recorded species were pooled together per lake for our analysis. The macrophytes were surveyed between 1954 and 2014.

\section{Denmark}

Most of the 49 Danish lakes included are located in central Jutland. Most lakes were meso- to eutrophic, alkaline systems with average depth ranging from 0.5 to $16 \mathrm{~m}$. A few humic and low alkaline (i.e., neutral pH or acid) lakes were included too. Macrophytes were surveyed at an area dependent number of observations point, ranging from 75 to 375 points, situated on equidistant transects covering the entire lake area (if shallow) or the potential macrophyte covered area (if deeper) (Johansson and Lauridsen, 2014). Observation points were distributed ensuring similar observation numbers in each depth interval ( 0.25 to $1 \mathrm{~m}$ depth intervals). A relative species distribution, a total species list and percentage coverage were generated for each lake. Surveys were performed between July 1st and August 15th at maximum biomass and before senescence, during the period 2001-2010.

\section{Finland}


Majority of the studied 261 lakes were shallow, small humic lakes and many of them were impacted by anthropogenic pressures (i.e., agriculture and urban development). Lake macrophytes were surveyed using a main belt transect method (Kanninen et al., 2013), in which a five-metrewide transect extends (perpendicularly to the shoreline) from the upper eulittoral to the outer depth limit of vegetation. The transect is divided into zones according to the dominant life-form or species. The number of transects varied depending on lake size. Lake macrophytes are observed by wading or by boat, with the aid of rake and hydroscope. The surveys were done between June and September over the period 2002-2011.

\section{Hungary}

All the studied 50 lakes are small, shallow lakes located in an agricultural landscape. Lake macrophytes were surveyed using a transect method. The number of transects parallel to shoreline varied according to lakes size (Schaumburg et al., 2007). All parallel transects contained minimum of four belt transects (two metre wide and perpendicular to the shoreline) extended from the upper eulittoral to the outer depth limit of vegetation. Field surveys were conducted between June and September over the period 2004-2012.

Italy

Majority of the studied 22 lakes were deep, big lakes and impacted by anthropogenic pressures (i.e., agriculture and urban development). Lake macrophytes were surveyed along transects (Azzella et al., 2013; Bolpagni, 2013). Data on aquatic plant diversity and representativeness were collected from each 1-meter depth interval down to the maximum colonization depth. The number of transects varied depending on lake size and sampling effort was tested to evaluate the effectiveness in the evaluation of macrophyte biodiversity. An underwater camera connected to a monitor placed on the boat was used to assess species presence and cover, while a double row rake was used to collect samples to help with macrophyte species identification. The surveys were done between June and September over the period 2009-2010.

\section{Japan}

Lakes were selected from the database which describes native vascular aquatic plants in Japan (Nishihiro et al., 2014) and additional data from newly found literatures were added to the database. From the whole database, we used those lakes in this work, in which macrophyte data were surveyed between 1990 and 2014. Selected lakes were distributed between $29.85^{\circ}$ and $45.07^{\circ} \mathrm{N}$. Lake area ranged from 0.01 to $704.95 \mathrm{~km}^{2}$ (median $1.59 \mathrm{~km}^{2}$ ), and maximum depth ranged from 1 to $326 \mathrm{~m}$ (median $6.35 \mathrm{~m})$.

\section{Morocco}


Most studied lakes were shallow and were located in the mountains (Middle and High Atlas) or Atlantic plains. These lakes are used by local people for cattle grazing, recreation, water supply and medicinal plants. Lake macrophytes were surveyed on zones ( 3 x 3 meters) distributed along 2 permanent transects at right angles to one another. The number of zones varied between lakes according to their size. The distance between zones was 3 to 5 meters. All species (amphibious, aquatic) were inventoried, however, only hydrophytes were used in the analyses. Field surveys were executed between February and July over the period 2005-2013.

\section{New Zealand}

Macrophyte data was drawn from 205 lakes that were surveyed using the "Quick Survey Method" of Clayton (1983). Surveyed lakes represented mostly of natural water bodies; however, 28 artificial reservoirs were included in the data. As a result, the lakes included those of volcanic origin, glacial formation, dammed rivers, dune, peat and land slip-formed lakes. Lakes were biased towards larger waterbodies located in accessible and populated areas. Consequently lakes included those influenced by anthropogenic nutrient enrichment or by the introduction of alien plants and fish. The timing of surveys was primarily in the austral spring to autumn (November to April), however most submerged species are perennial and present year round. Between 1 and 50 sites were assessed, with generally more sites in larger lakes. At each site scuba divers covered a $2 \mathrm{~m}$ wide transect from the shoreline water level to the deepest extent of vegetation, identifying all plant species seen, with the exception of bryophytes.

\section{Norway}

The studied 30 high-alkalinity lakes are small in surface area, varying from oligotrophic to eutrophic status and subject to agricultural land use pressure. These lakes situate in Nord-Trøndelag county in the middle of Norway. Lake macrophytes were surveyed along four orthogonal transects perpendicular to the lake shore and situated approximately at its intersection with the four cardinal points (Viana et al., 2014). In addition, the rest of the lake and its edges were visited, and any additional species recorded. The surveys were carried out during the peak of the growing season in 1998 , so that all species present in the lake through the season could be detected. Only hydrophytes were used in the analyses.

\section{Poland}

All of the 475 lakes are lowland ( $<200 \mathrm{~m}$ a.s.1.), with high-alkalinity non-coloured waters, but differ in morphometry and trophy. Data on macrophytes were collected in the period 2004-2012 within the national lake monitoring programme (425 lakes) and other research projects. Lake macrophytes were surveyed between June and September using the unified field survey procedure based on belt transect method (Ciecierska and Kolada, 2014). The number of transects varied depending on lake size; however, sampling effort has not influenced previous studies on macrophyte community 
compositions (Kolada et al, 2014). Within the phytolittoral of each lake, the maximum colonisation depth, the mean vegetation coverage and the relative cover of all the aquatic and emergent plant communities were determined. Only hydrophytes were used in our work.

\section{Salga project (Brazil, Uruguay and Argentina)}

The studied lakes situated across the three countries and were small $\left(0.09-2.53 \mathrm{~km}^{2}\right)$ shallow (mean depth $<4.5 \mathrm{~m}$ ) and varied greatly in the degree in which they were impacted by anthropogenic pressures (i.e., agriculture and urban development) (Kosten et al., 2009a). Lake macrophytes were surveyed based on observations along $3-8$ parallel transects perpendicular to the maximum length of the lake and an additional 20 randomly located points. The number of transects varied with the shape and size of the lake. Observations were made from a boat using a rake when necessary (Kosten et al., 2009b; Kosten et al., 2009c). The surveys were done during summer (lakes at latitudes below $30^{\circ} \mathrm{S}$ ) or during dry season (lakes above $30^{\circ} \mathrm{S}$ ) between November 2004 and March 2006 by the same team.

\section{Spain}

We enclose data on 66 water bodies holding macrophyte flora and sampled between 2005 and 2009 across Catalonia (NW Spain). The data set includes a diversity of water body typologies from alpine lakes (at high altitude with oligotrophic soft-waters), karstic lakes (high alkaline waters), coastal lagoons (at the shoreline, with brackish waters), permanent ponds and temporary pools (small ponds with annual desiccation period). Water bodies were usually small and shallow and were located along a large altitudinal range ( 0 - $2573 \mathrm{~m}$ a.s.1.). Sampling was conducted by snorkeling, scuba diving or walking with waders around all the water body and collecting macrophyte samples at the different assemblages that were recognized by visual inspection (Chappuis et al., 2014).

\section{Sweden}

The studied 379 lakes varied in their environmental conditions and subjectivity to anthropogenic pressures. Macrophyte surveys were conducted between 2008 and 2013 using a transect method, in which the transects were placed perpendicular to the shoreline and distributed around the lake, from the upper eulittoral to the outer limit of vegetation. The number of transects varied according to lake size with larger lakes having more transects and vice versa. Species were identified by diving along the transects with $0.5 \mathrm{~m}$ in 20 -cm depth intervals and in plots of ca. $25 \times 50 \mathrm{~cm}$ (Naturvårdsverket, 2010).

\section{Switzerland}


The water bodies (i.e. ponds and small lakes, with an area less than 1 ha) included in this study are scattered throughout Switzerland along an altitudinal gradient ranging from lowland (305 m.a.s.1.) to alpine areas (2191 $\mathrm{m}$ a.s.1.). A fifth of them are of natural origin, whereas the other originated from past or present anthropic activities. The macrophytes of all ponds and lakes were surveyed using a standardized method based on plot sampling $(0.5 \times 0.5 \mathrm{~m})$ along transects (Oertli et al., 2005). The transects were positioned perpendicularly to the longest axis of the water body, at intervals of $5 \mathrm{~m}$ for small and $20 \mathrm{~m}$ for larger ponds. The number of plots was proportional to the area of the water body and positioned at $5 \mathrm{~m}$ intervals along transects. The surveys were carried out between June and September over the period $1996-2004$.

\section{US state of Florida}

The 205 Florida study lakes ranged from oligotrophic to hypereutrophic with average chlorophylls ranging from $<1.0 \mu \mathrm{g} / \mathrm{L}$ to over $150 \mu \mathrm{g} / \mathrm{L}$. The lakes were generally shallow and small with $75 \%$ of the mean depths less than $4.0 \mathrm{~m}$ and $75 \%$ of the surface areas less than 200 ha. Plant sampling was conducted during summer months between 1991 and 2013 with a varying number of transects per lake depending on the size of the lake (generally 10 transects per lake). The transects were placed uniformly around the lake and went from open water through the littoral zone of each transect. Plants were collected with divers in deep-water areas and rakes in shallow areas and all identified to species. In addition to species composition, total abundance of all plants in each lake (PAC: percent area covered and PVI: percent volume infested with aquatic plants) was estimated using ecosounding technologies. Both aquatic plant species composition and abundance was measured to examine plant relations to the Limnology of Florida lakes and to assist state agencies with the management of aquatic plants.

\section{US state of Minnesota}

Aquatic macrophyte data from 441 lakes were used, covering the entire US state of Minnesota. Environmental conditions of the study lakes varied from more natural water bodies with lower nutrient and alkalinity values in the northern part of the state to severely anthropogenic-impacted lakes with high trophic status situated in the south (Alahuhta, 2015). The macrophyte data were collected by the Minnesota Department of Natural Resources (Section of Fisheries) between 1992 and 2003. The aquatic plant species were sampled between July and August using a transect method, in which transects were evenly placed around the lake. The 6-m wide transects ran perpendicular to the shore to the maximum depth of vegetation cover, and the number of transects varied depending on lake size. The species were identified from a boat with the help of a grapple.

\section{US state of Wisconsin}

Macrophyte data from 409 Wisconsin lakes were surveyed between May and September from 2005-2012 using a point-intercept method as outlined in Hauxwell et al. 2010. Species were 
observed from a boat using a double-sided rake sampler at a grid of points projected onto the surface of each lake. Spatial resolution of sample points was calculated as a function of estimated lake littoral area and shoreline complexity as in Mikulyuk et al. 2010. Spatial extent covered the three lake-rich ecoregions of Wisconsin and lakes represent the full gradient of anthropogenic impact, primary productivity, alkalinity, and hydrologic type present in the region (Omernik, 2000; Riera et al., 2000; Mikulyuk 2010). 


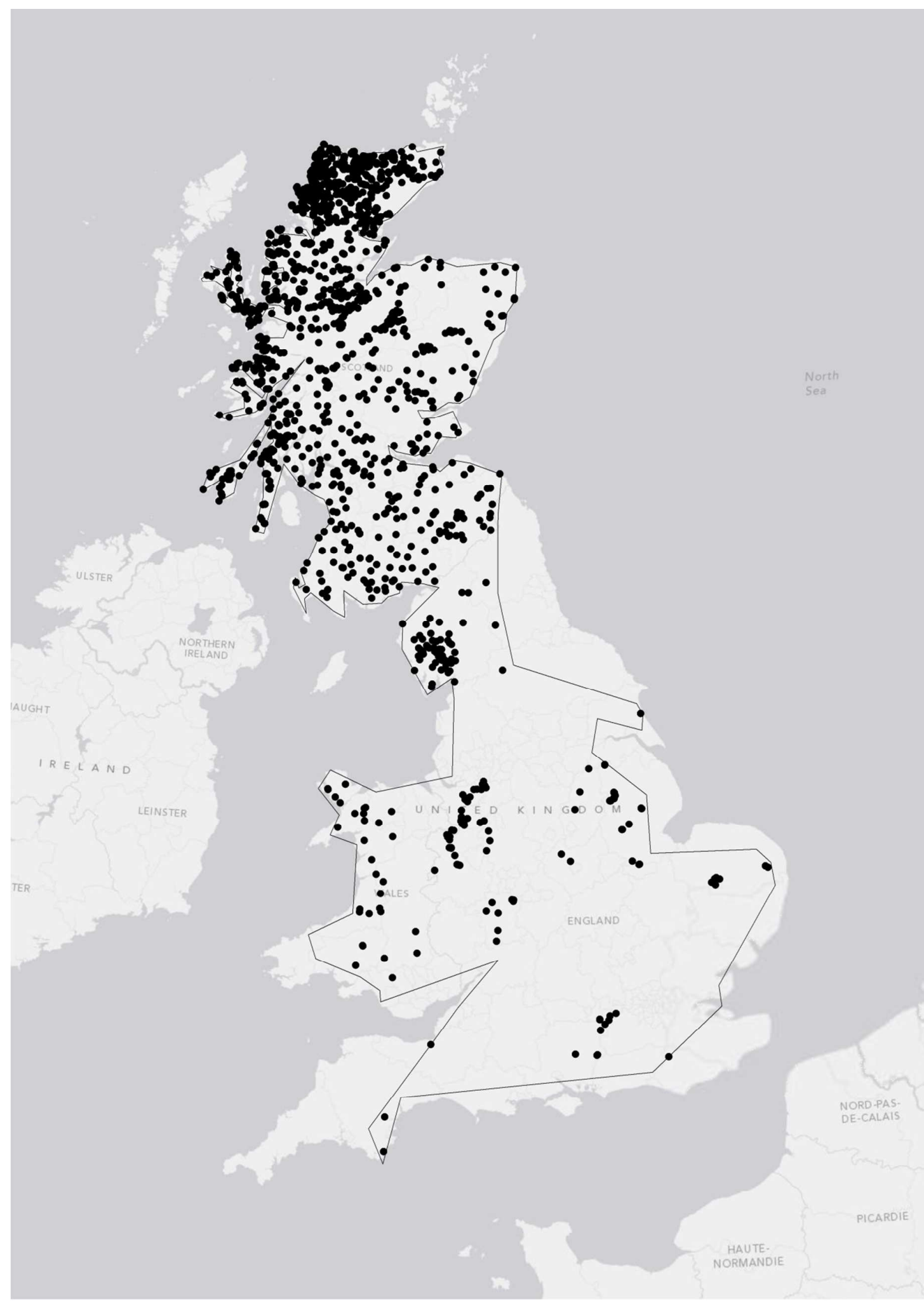

Appendix S2. An example of convex hull drawn for UK macrophyte data. 
Appendix S3. Correlation matrix among environmental variables used in the study. Clay: modelled soil clay, No of spp.: Number of species recorded in lakes within a region, Org. soil C: Organic soil carbon, Annual ${ }^{\circ} \mathrm{C}$ : Annual temperature, Waters: Proportion of freshwaters within a region, $\mathrm{p}: * * * \leq 0.001, * *<0.05, *<0.1$.

\begin{tabular}{|c|c|c|c|c|c|c|c|c|c|c|}
\hline & $\begin{array}{l}\text { Alkalinity } \\
\text { range }\end{array}$ & $\begin{array}{l}\text { Altitude, } \\
\text { mean }\end{array}$ & $\begin{array}{l}\text { Altitude, } \\
\text { range }\end{array}$ & Clay & Latitude & $\begin{array}{l}\text { Org. soil C, } \\
\text { range }\end{array}$ & $\begin{array}{l}\text { Spatial } \\
\text { extent }\end{array}$ & $\begin{array}{l}\text { Annual }{ }^{\circ} \mathrm{C}, \\
\text { mean }\end{array}$ & $\begin{array}{l}\text { Annual }{ }^{\circ} \mathrm{C} \text {, } \\
\text { range }\end{array}$ & Waters \\
\hline Alkalinity range & 1 & 0.01 & 0.29 & -0.03 & 0.01 & -0.10 & $0.52 * *$ & 0.01 & 0.29 & 0.08 \\
\hline Altitude mean & & 1 & $0.73 * * *$ & $0.37 *$ & -0.22 & 0.03 & -0.11 & 0.01 & $0.57 * *$ & $-0.33^{*}$ \\
\hline Altitude range & & 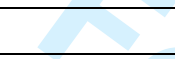 & 1 & $0.34 *$ & -0.16 & 0.02 & 0.27 & 0.04 & $0.92 * * *$ & $-0.35^{*}$ \\
\hline Clay & & 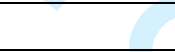 & & 1 & $-0.76 * * *$ & $-0.56 * *$ & $-0.31 *$ & $0.82 * * *$ & 0.22 & $-0.44 * *$ \\
\hline Latitude & & 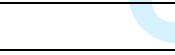 & 8 & & 1 & $0.35 *$ & 0.11 & $-0.83 * * *$ & -0.12 & 0.24 \\
\hline $\begin{array}{l}\text { Org. soil C, } \\
\text { range }\end{array}$ & & & & & & 1 & $-0.54 * *$ & $-0.51 * *$ & 0.26 & $0.39 *$ \\
\hline Spatial extent & & & & & & & 1 & $-0.43 * *$ & $-0.48 * *$ & 0.08 \\
\hline $\begin{array}{l}\text { Annual }{ }^{\circ} \mathrm{C}, \\
\text { mean }\end{array}$ & & & $\theta$ & & & & & 1 & -0.03 & $-0.41^{*}$ \\
\hline $\begin{array}{l}\text { Annual }{ }^{\circ} \mathrm{C}, \\
\text { range }\end{array}$ & & & & 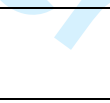 & & & & & 1 & -0.24 \\
\hline Waters & & & & & $8=$ & & & & & 1 \\
\hline
\end{tabular}


- Sørensen $\Delta$ Species turnover $\square$ Nestedness

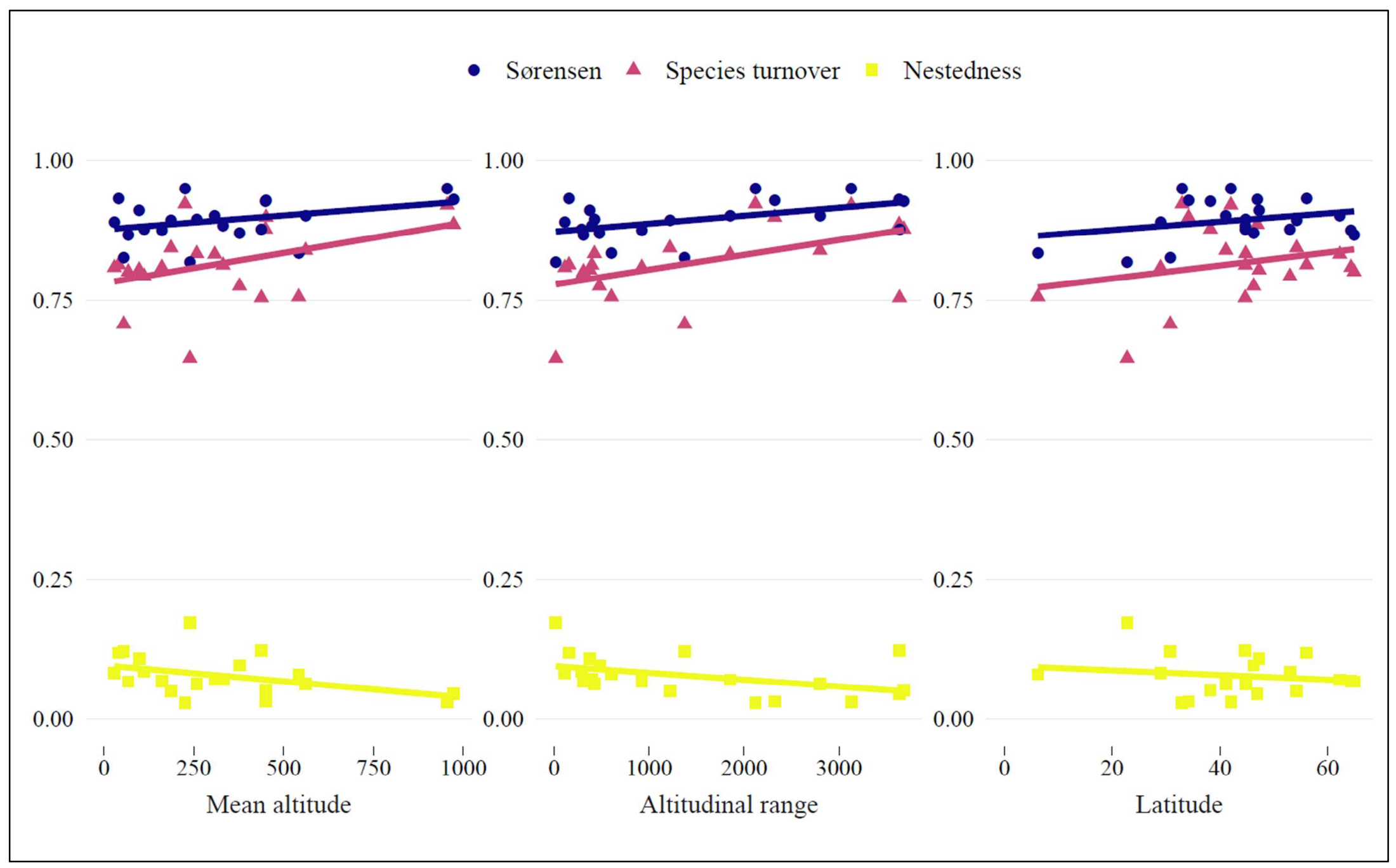

Appendix S4. Relationships between pairwise-site beta diversity dissimilarities (i.e., Sørensen, species turnover and nestedness) and mean altitude, altitudinal range and latitude. 


\section{References}

Alahuhta, J. (2015) Geographic patterns of lake macrophyte communities and species richness at regional scale. Journal of Vegetation Science, $26,564-575$.

Azzella, M.M., Ricotta, C. \& Blasi, C. (2013) Aquatic macrophyte diversity assessment: Validation of a new sampling method for circularshaped lakes. Limnologica, 43, 492-499.

Bolpagni, R. (2013) Multimetric indices based on vegetation data for assessing ecological and hydromorphological quality of a man-regulated lake. Annali Botanica, 3, 87-95.

Chappuis, E., Gacia, E. \& Ballesteros, E. (2014) Environmental factors explaining the distribution and diversity of vascular aquatic macrophytes in a highly heterogeneous Mediterranean region. Aquatic Botany, 113, 72-82.

Ciecierska, H. \& Kolada, A. (2014) ESMI: a macrophyte index for assessing the ecological status of lakes. Environmental Monitoring and Assessment, 186, 5501-5517.

Clayton, J.S. (1983) Sampling aquatic macrophyte communities. In: Biggs BJ, Gifford JS, Smith DG ed. Biological methods for water quality surveys. Water and Soil Miscellaneous Publication 54. Wellington, New Zealand, Ministry of Works and Development

Crowder, A.A., Bristow, J.M., King, M.R. \& Vanderkloet, S. (1977) Distribution, seasonality, and biomass of aquatic macrophytes in Lake Opinicon (Eastern Ontario). La Naturaliste Canadien, 104, 441-456.

Duigan, C., Kovach, W. \& Palmer, M. (2007) Vegetation communities of British lakes: a revised classification scheme for conservation. Aquatic Conservation-Marine and Freshwater Ecosystems, 17, 147-173.

Gecheva, G., Dimitrova-Dyulgerova, I., Cheshmedjiev, S. (2013) Macrophytes. In: Belkinova, D. \& Gecheva, G. (eds.), Biological analysis and ecological status assessment of Bulgarian surface water ecosystems, Plovdiv University Publishing House, Plovdiv, 127-146 (in Bulgarian). 
Hauxwell, J., Knight, S., Wagner, K., Mikulyuk, A., Nault, M., Porzky, M. \& Chase, S. (2010) Recommended baseline monitoring of aquatic plants in Wisconsin: Sampling design, field and laboratory procedures, data entry and analysis, and applications. Miscellaneous publication PUB-SS1068. Madison (WI): Wisconsin Department of Natural Resources.

Hitchin, G.G., I. Wile, G.E. Miller \& N.D. Yan. (1984) Macrophyte data from 46 southern Ontario soft-water lakes of varying pH. Ontario Ministry of Environment Data Report DR 84/2.

Johansson, L. S. \& Lauridsen, T. L. (2014) Planteundersøgelser i søer. Teknisk anvisning S04. Aarhus Universitet, DCE Nationalt Center for Miljø og Energi. Available at: http://bios.au.dk/fileadmin/bioscience/Fagdatacentre/Ferskvand/S04_makrofyter_ver2_20140620.pdf

Kanninen, A., Vallinkoski, V.-M., Leka, J., Marjomäki, T. J., Hellsten, S. \& Hämäläinen, H. (2013) A comparison of two methods for surveying aquatic macrophyte communities in boreal lakes: implications for bioassessment. Aquatic Botany, 104, 88-100.

Kohler, A. (1978) Methoden der Kartierung von Flora und Vegetation von Süßwasserbiotopen. Landschaft \& Stadt, 10, 73-85.

Kolada, A., Ciecierska, H., Ruszczyńska, J. \& Dynowski, P. (2014) Sampling techniques and inter-surveyor variability as sources of uncertainty in Polish macrophyte based metric for lake ecological status assessment. Hydrobiologia, 737, 256-279.

Kosten S, Huszar, V.L.M., Mazzeo, N., Scheffer, M., Sternberg, L.D.S.L. \& Jeppesen, E. (2009a) Lake and watershed characteristics rather than climate influence nutrient limitation in shallow lakes. Ecological Applications, 19, 1791-1804.

Kosten, S., Kamarainen, A., Jeppesen, E., Van Nes, D., Peeters, E.T.H.M., Mazzeo, N., Hauxwell, J., Hansel-Welch, N., Lauridsen, T.L., Søndergaard, M., Bachmann, R.W., Lacerot, G. \& Scheffer, M. (2009b) Climate-related differences in the dominance of submerged macrophytes in shallow lakes. Global Change Biology, 15, 2503-2517.

Kosten, S., Lacerot, G., Jeppesen, E., Da Motta Marques, D., Van Nes, E.H., Mazzeo, N. \& Scheffer, M. (2009c) Effects of submerged vegetation on water clarity across climates. Ecosystems, 12, 1117-1129. 
Mikulyuk, A., Hauxwell, J., Rasmussen, P., Knight, S., Wagner, K.i., Nault, M.E. \& Ridgely, D. (2010) Testing a methodology for assessing plant communities in temperate inland lakes. Lake and Reservoir Management, 26, 54-62.

Miller, G. E., \& Dale, H. M. (1979) Apparent differences in aquatic macrophyte floras of eight different lakes in Muskoka District, Ontario from 1953 to 1977. Canadian Field Naturalist, 93, 386-390.

Naturvårdsverket (2010) Handledning för miljöövervakning - Undersökningstyp: Makrofyter i sjöar. Available at URL: https://www.havochvatten.se/download/18.64f5b3211343cffddb280004851/Makrofyter+i+sj\%C3\%B6ar.pdf

Neil, J., Graham, J. \& Warren, J. (1991) Aquatic Plants of Cook Bay, Lake Simcoe, 1987. Lake Simcoe Environmental Management Strategy, Technical report B.4.

Nishihiro, J., Akasaka, M., Ogawa, M. \& Takamura, N. (2014) Aquatic vascular plants in Japanese lakes. Ecological Research, $29,369-369$.

Omernik, J. M., Chapman, S. S., Lillie, R.A. \& Dumke, R.T. (2000) Ecoregions of Wisconsin. Transactions of the Wisconsin Academy of Sciences, Arts and Letters 88, 77-103.

Ontario Ministry of the Environment and Ministry of Natural Resources (1976) The Kawartha Lakes Water Management Study - Water Quality Assessment (1972 - 1976). Toronto, Ontario.

Oertli B., Auderset Joye D., Castella E., Juge R., Lehmann A. \& Lachavanne J-B. (2005) PLOCH: a standardized method for sampling and assessing the biodiversity in ponds. Aquatic Conservation: Marine and Freshwater Ecosystems, 15, 665-679.Schaumburg, J., C. Schranz, D. Stelzer, G. Hofmann (2007) Action Instructions for the ecological Evaluation of Lakes for Implementation of the EU Water Framework Directive: Makrophytes and Phytobenthos. Bavarian Environment Agency, 69.

Riera, J. L., Magnuson, J. J., Kratz, T.K. \& Webster, K.E. (2000) A geomorphic template for the analysis of lake districts applied to the Northern Highland Lake District, Wisconsin, U.S.A. Freshwater Biology, 43, 301-318. 
Schaumberg, J., Schranz, C., Foerster, J., Gutowski, A., Hofmann, G., Meilinger, P., Schneider, S. \& Schmedtje, U. (2004) Ecological classification of macrophytes and phytobenthos for rivers in Germany according to the water framework directive. Limnologica, 34, 283301.

Schloesser, D.W., Edsall, T.A. \& Manny, B.A. (1985) Growth of submerged macrophyte communities in the St. Clair - Detriot river system between Lake Huron and Lake Erie. Canadian Journal of Botany, 63, 1061-1065

Viana, D.S., Santamaria, L., Schwenk, K., Manca, M., Hobæk, A., Mjelde, M., Preston, C.D., Gornall, R.J., Croft, J.M., King, R.A. Green, A.J. \& Figuerola, J. (2014) Environment and biogeography drive aquatic plant and cladoceran species richness across Europe. Freshwater Biology, 59, 2096-2106.

Wile, I. \& Hitchin, G. (1977) An assessment of the practical and environmental implications of mechanical harvesting of aquatic vegetation in Southern Chemung Lake. Ministry of the Enviornment and Ministry of Natural Resources, Toronto, Ontario. 